\title{
Systematic Review of Sleep Disturbances and Circadian Sleep Desynchronization in Autism Spectrum Disorder: Toward an Integrative Model of a Self-Reinforcing Loop
} Claudia Carmassi ${ }^{1}$, Laura Palagini ${ }^{1 *}$, Danila Caruso ${ }^{1}$, Isabella Masci ${ }^{1}$, Lino Nobili ${ }^{2,3}$,
Antonio Vita ${ }^{4}$ and Liliana Dell'Osso ${ }^{1}$

OPEN ACCESS

Edited by:

Armida Mucci,

Università degli Studi della Campania

Luigi Vanvitelli Caserta, Italy

Reviewed by:

Emilio Baliki Liociri Ovuga,

Gulu University,

Uganda

Saeeda Paruk,

University of KwaZulu-Natal,

South Africa

*Correspondence:

Laura Palagini

Ipalagini@tiscali.it

I.palagini@tiscali.it

Specialty section:

This article was submitted to

Social Psychiatry and

Psychiatric Rehabilitation,

a section of the journal

Frontiers in Psychiatry

Received: 25 February 2019

Accepted: 13 May 2019

Published: 06 June 2019

Citation:

Carmassi C, Palagini L, Caruso D,

Masci I, Nobili L, Vita $A$ and

Dell'Osso L (2019) Systematic

Review of Sleep Disturbances and

Circadian Sleep Desynchronization

in Autism Spectrum Disorder:

Toward an Integrative Model of

a Self-Reinforcing Loop.

Front. Psychiatry 10:366.

doi: 10.3389/fpsyt.2019.00366
${ }^{1}$ Department of Clinical and Experimental Medicine, Psychiatry Division, University of Pisa, Pisa, Italy, ${ }^{2}$ Child Neuropsychiatry Unit, IRCCS G. Gaslini Institute, Genova, Italy, ${ }^{3}$ Department of Neuroscience-Rehabilitation-Ophthalmology-Genetics-Child and Maternal Health (DINOGMI), University of Genova, Genova, Italy, ${ }^{4}$ Psychiatry Division, Department of Clinical and Experimental Medicine, University of Brescia, Brescia, Italy

Background: A compelling number of studies, conducted in both children and adults, have reported an association between sleep disturbances/circadian sleep alterations and autism spectrum disorder (ASD); however, the data are sparse and the nature of this link is still unclear. The present review aimed to systematically collect the literature data relevant on sleep disturbances and circadian sleep dysrhythmicity related to ASD across all ages and to provide an integrative theoretical framework of their association.

Methods: A systematic review of the MEDLINE, PubMed, and Cochrane databases was conducted from November 2018 to February 2019. The search strategies used were MeSH headings and keywords for "sleep-wake circadian rhythms" OR "circadian sleep disorders" OR "sleep-wake pattern" OR "sleep disorders" OR "melatonin" AND "autism spectrum disorder" OR "autism".

Results: One hundred and three studies were identified, 15 regarded circadian sleep dysrhythmicity, 74 regarded sleep disturbances, and 17 regarded melatonin alterations in children and adults with ASD. Our findings suggested that autistic subjects frequently present sleep disturbances in particular short sleep duration, low sleep quality/efficiency, and circadian sleep desynchronization such as delayed phases and/or eveningness. Sleep disturbances and circadian sleep alterations have been related to the severity of autistic symptoms. Genetic studies have shown polymorphisms in circadian CLOCK genes and in genes involved in melatonin pathways in subjects with ASD.

Conclusions: Sleep disturbances and circadian sleep alterations are frequent in subjects with autistic symptoms. These subjects have shown polymorphisms in clock genes expression and in genes involved in melatonin production. The impairment of circadian sleep regulation may increase the individual's vulnerability to develop symptoms of ASD by altering the sleep regulation in toto, which plays a key role in normal brain development. 
Even though controversies and "research gaps" are present in literature at this point, we may hypothesize a bidirectional relation between circadian sleep dysfunction and ASD. In particular, circadian sleep dysrhythmicity may predispose to develop ASD symptoms and vice versa within a self-reinforcing feedback loop. By targeting sleep disturbances and circadian sleep dysrhythmicity, we may improve treatment strategies for both children and adults with ASD.

Keywords: autism spectrum disorder, circadian rhythms, sleep disturbances, neurodevelopmental, melatonin, clock genes

\section{HIGHLIGHTS}

- Children and adults with autistic symptoms often experience sleep disturbances and alterations in circadian sleep rhythmicity.

- Children and adults with autistic symptoms have shown mutations and polymorphisms in clock gene expression related to irregular and delayed sleep phases and to sleep problems.

- Abnormalities in the expression of genes regulating melatonin pathways may be responsible for low melatonin levels and for circadian sleep disturbances in subjects with autistic symptoms.

- Genetic abnormalities in the circadian system may impair the sleep system in toto with negative consequences on brain development contributing to autistic symptoms.

- The impairment of circadian sleep rhythmicity may increase the individual's vulnerability to develop symptoms of autism spectrum disorder.

- Vice versa, alteration in brain development related to autism spectrum disorder autistic symptoms may contribute to sleep disturbances within a self-reinforcing loop.

- The evaluation and treatment of circadian sleep disorders in autism spectrum disorders may be useful to improve the trajectories of subjects with autistic symptoms.

\section{INTRODUCTION}

Autism spectrum disorder (ASD) is an early-onset neurodevelopmental disorder whose core features have been defined by the Diagnostic and Statistical Manual of Mental Disorders, Fifth Edition (DSM-5) (1). It is characterized as persistent difficulties in social interaction and communication, presence of stereotypic behaviors, restricted interests, and atypical sensory reactivity. ASD, in fact, encompasses a set of clinical phenotypes that includes previously described autistic disorder (AD) and Asperger syndrome (AS), from severe to mild variants as endpoints of a continuum upon a spectrum model approach $(2,3)$. Intellectual disability is observed in more than half of ASD cases $(4,5)$ and ASD autistic symptoms also affect social language skills and emotion regulation. In addition, ASD symptoms are often related to coexisting mental disorders and to other developmental disorders (6).

Within the last decades, the diagnosis rate of autism has increased dramatically, and it has been reported that cases of
ASD have a rate of $0.6-0.8 \%$ in preschool children, $1.0 \%$ in school children and young adults, and around $1.0 \%$ in adults $(7,8)$. In the last few years, an increased interest has been developed for mild forms of ASD, which often remain undiagnosed or misdiagnosed until adulthood. Although ASD is defined as a developmental disorder because symptoms appear within the first 2 years of life, it is generally considered a lifelong disorder with negative consequences on scholastic, working, social, and economic performances and quality of life. Some studies have shown that mild forms of autism are related to high rates of psychiatric comorbidity in adulthood such as anxiety, mood disorders, psychosis, stress-related disorders, and suicidal behaviors $(9,10)$.

In this framework, understanding the mechanisms involved in the development of ASD should be a priority for identifying early markers that could help improve early diagnosis with a significant impact on lifelong prognosis (3). The mechanisms underlying the development of ASD may be the result of the interaction between multiple gene arrangement and the environment that may lead to the alteration of brain structures and functions $(11,12)$. This interaction may determine epigenetic alterations disrupting the regulation of gene expression with a negative impact on biological pathways relevant for brain development (13). Abnormalities during brain development in autistic subjects go beyond the "social brain" encompassing sensory processing and attentional control. In fact, current evidence strongly supports a model of brain-wide abnormalities during the early development of autistic children (12). Indeed, it remains an open question if a single mechanism or several independent factors can lead to the emergence of autism.

In the last few years, a new hypothesis has emerged, suggesting the role of circadian system desynchronization in the development of ASD $(11,14)$. Human physiological and biochemical processes as well as behavioral patterns have a circadian rhythmicity orchestrated by the master biological clock of the hypothalamus: the suprachiasmatic nuclei (SCN). The expression of many genes changes rhythmically over $24 \mathrm{~h}$ and the specific circadian genes are responsible for the main SCN clock-working machinery as well as that of subsidiary clocks at the peripheral level [among them: circadian locomotor output cycles kaput (CLOCK), brain and muscle ARNT-like protein 1 (BMAL1), cryptochromes CRY1-2, and band period homolog (PER)] [(15, 16); for an overview see Ref. (17)]. The suprachiasmatic nuclei is daily synchronized by environmental signals such as light, food intake, 
activities, or social cues and exposure to stress/trauma (18-20), and while driving, secretion of the melatonin hormone regulates peripheral clock within feed-forward mechanism. Rhythmic clock gene expression regulates multiple monoaminergic brain regions that control mood and motivational behaviors, stress and inflammatory systems, reward circuits, arousal, and sleep by interacting with the homeostatic regulation of sleep and wake [for an overview, see Refs. $(17,21)]$. The circadian system is critical for the synchronization with the environment and allows a correct functioning of various internal physiological processes essential for the optimization of responses to environmental fluctuations and for the strengthening of homeostatic control mechanisms (21). Abnormalities in the maturation of the circadian system principally lead to alterations in the sleep-wake pattern (22), which may interest around $50-80 \%$ of subjects with ADs (23). Wimpory and colleagues (24) have hypothesized that timing and social timing deficits were relevant in subjects with AD symptoms and were related to pathological variations in the structure/ function of clock/clock-related genes: the authors hypothesized a key role for circadian sleep dysregulation in autistic symptoms. This hypothesis has been confirmed by later studies, which have shown circadian-relevant gene abnormalities in $\operatorname{ADs}(25,26)$. Mutations in Clock, Bmal1, Cry1, and Cry2 genes determine an alteration in the circadian system regulation as well as in sleep fragmentation $(27,28)$. Sleep is increasingly recognized as a key process in neurodevelopment and in brain optimization processes [for an overview, see Ref. (29)]. Both humans and animals' data have shown that sleep is essential for maturation of fundamental brain functions, and epidemiological findings increasingly indicate that children with early sleep disturbances suffer from later cognitive, attentional, and psychiatric problems. Indeed, from birth throughout infancy and early childhood, sleep patterns undergo dramatic changes that include the gradual consolidation of sleep and waking cycles, the intensification of deep NREM sleep slow-wave activity (EEG power in the $1-4.5 \mathrm{~Hz}$ frequency range), and a progressive decrease of REM sleep proportion. It has been suggested that REM sleep is an inducer of brain development and of early myelination in the sensory processing areas in the fetus and the newborns and that it follows the maturational trajectory of the brain (29-34). Animal studies have shown that REM sleep has multifaceted functions in brain development, including learning and memory consolidation by selectively eliminating and maintaining newly formed synapses (35). On the other hand, slowwave sleep and sleep spindles $(10-14 \mathrm{~Hz})$ seem to be even involved in synaptic remodeling, being important for synaptic strength and synchronized neuronal firing, and it has been shown that while following the trajectory of brain maturation, they may orchestrate synaptic plasticity and pruning during brain development (30, 36-40). Particularly, Ringli and Huber hypothesized that slowwave sleep may contribute to cortical maturation by playing a role in the balance of brain synaptic strengthening/formation weakening/elimination that is tilted during development (39). Sleep promotes myelination and oligodendrocyte precursor cell proliferation (41), enhances transcription of genes involved in synthesis and maintenance of membranes and myelin too (42), and modulates the neuronal membrane homeostasis (43). Since adequate sleep has been proposed to be fundamental for brain development $(31,35,39)$, sleep has received considerable research attention, as it appears to be important in the study of neurodevelopmental psychopathology (31, 39, 44-46). Hence, if sleep is fundamental for brain development, we may hypothesize that sleep disturbances, via alterations in brain development, may contribute to autistic symptoms. This idea has been previously developed for other psychiatric disorders. In fact, extensive data have shown that poor sleep during childhood and adolescence is related to alterations in brain development $(39,44,47-53)$ to problems in cognitive, attentional, emotional, and behavioral areas, including risk-taking and aggression; and to psychiatric conditions such as attention deficit hyperactivity disorder and mood disorders (54). Indeed, we may also hypothesize that alteration in brain development related to ASD may contribute to sleep disturbances within a self-reinforcing loop.

\section{OBJECTIVES}

On this basis, this review was aimed to systematically collect the literature data relevant on sleep disturbances and circadian sleep dysrhythmicity related to ASD across all ages; a comprehensive review that has been conducted recently was limited to youth (55). In particular, we aimed to construct an integrative theoretical framework of their association: a comprehensive framework would be quite useful from a clinical and therapeutic point of view for identifying elements to evaluate and target in the clinical practice.

The hypothesis of this review was that abnormal maturation of the circadian sleep system may lead to the disruption of the sleep system in toto that, by impairing brain neurodevelopment and melatonin production, may have a key role in ASD. The investigation of such elements may be helpful to a better understanding of the neurodevelopmental pathways of ASD. Hence, the aim of this review was to systematically collect the literature data on sleep and circadian disturbances in children and adults with ASD.

\section{METHODS}

\section{Search Strategy}

We performed a systematic review, based on Preferred Reporting Items for Systematic Review and Meta-analyses (PRISMA) guidelines, of articles published up till February 2019, and indexed in the following databases: MEDLINE, PubMed, and Cochrane Library. The search strategies used MeSH headings and keywords for "sleep-wake circadian rhythms" OR "circadian sleep disorders" OR "sleep-wake pattern" OR "sleep disorders" OR “melatonin” AND “autism spectrum disorder" OR “autism.”

Inclusion criteria: The searches were limited to the English language studies conducted on human populations, including longitudinal, cross-sectional, or case-control studies, analyzing the relationship between sleep disturbances and/or circadian sleep disorders and ASD.

Exclusion criteria: Studies that did not have as principal focus the evaluation of sleep disturbances and/or circadian sleep 
rhythms related to autism were excluded. We also excluded studies that investigated subjects with other neurodevelopmental disorders or intellectual disabilities.

\section{Data Extraction}

The abstracts located from the search strategy were entered into EndNote. The searches were limited to the English language studies conducted on human populations, including longitudinal, cross-sectional, or case-control studies, analyzing the relationship between sleep disturbances and/or circadian sleep disorders and ASD. Title and abstracts of all non-duplicated papers were independently screened by two of the authors (DC and IM). Potential pertinent papers were retained and assessed for eligibility by screening the full text. Two senior authors (LP and CC) acted as arbitrators when there is disagreement in any screening stage. All the authors independently evaluated the quality of the included studies. Disagreements between authors were resolved by consensus. Initial literature search returned 1,443 records (among which 7 studies were searched manually from other sources), 652 after exclusion of duplicates. Following preliminary screening of the titles and the exclusion of reviews and case reports, 492 of the retrieved articles were excluded; further 57 records were excluded after reading abstracts and full texts based on the relevance of data for the aim of the present study (Figure 1).

\section{Data Analysis}

Meta-analysis was not conducted due to heterogeneity in definition and measurement of outcomes.

\section{RESULTS}

The systematic review of literature returned 103 articles focused on the sleep-wake pattern in neurodevelopmental disorders on children and an adult population according to the evolution of nosography; these studies include both previously defined diagnoses (56), such as $\mathrm{AD}$, AS, childhood disintegrative disorder (CDD), pervasive developmental disorder (PDD), and not otherwise specified (NAS) (2), and the most recent diagnosis of ASD (1).

\section{Circadian Sleep Dysrhythmicity in Children With ASD}

Seven studies have evaluated the alterations of circadian rhythms in children with ASD (Table 1). The first study (57) reported no tendency for irregular sleep-wake pattern, delayed sleep phase syndrome, or advanced sleep phase syndrome in children with ASD. Similar results were found in another study and in addition, no circadian phase preference was detected (61). On the other hand, several studies have shown that children with ASD may

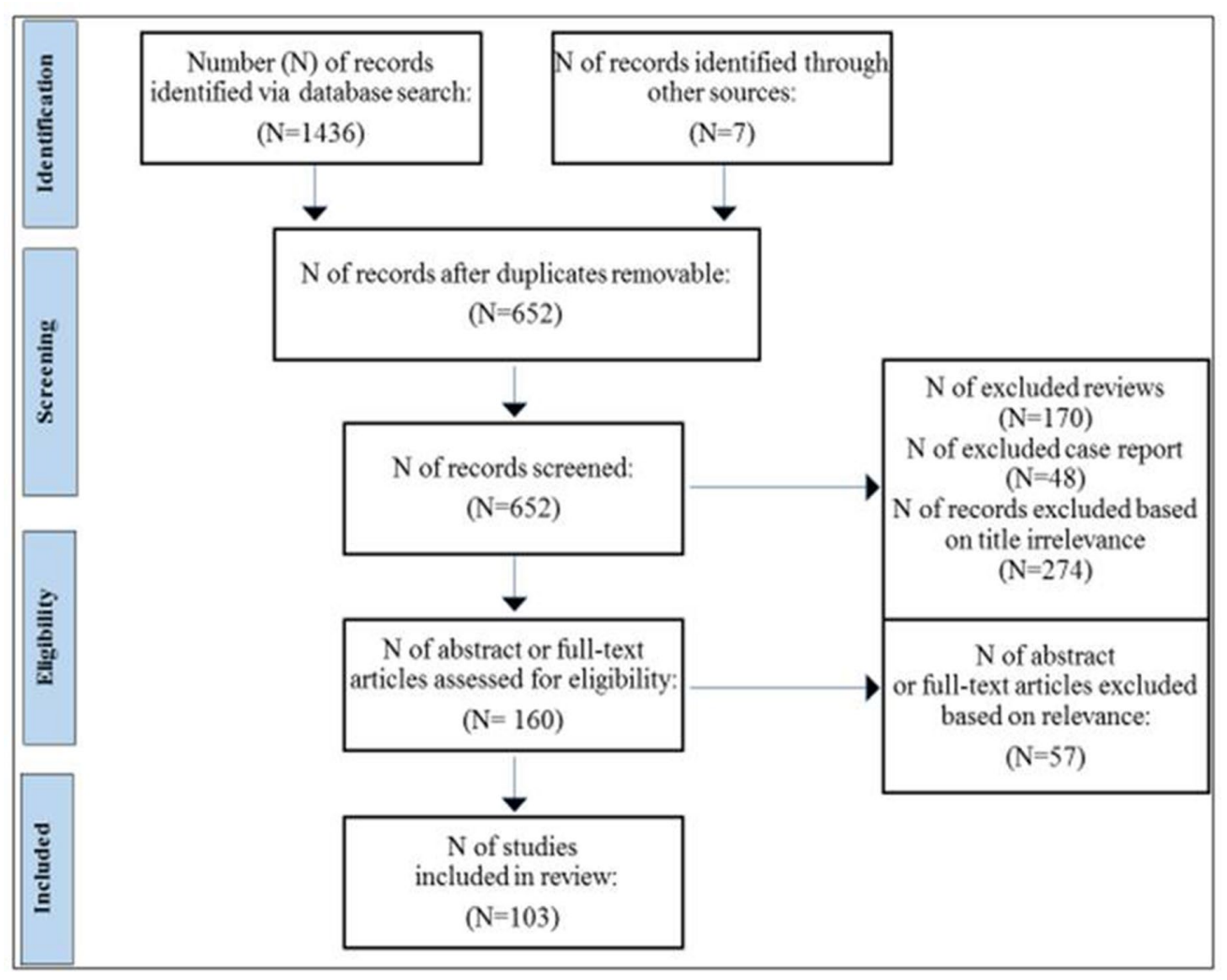

FIGURE 1 | Flow chart based on PRISMA guidelines. 
TABLE 1 | Clinical studies on circadian rhythmicity and autism spectrum disorder in children

\begin{tabular}{|c|c|c|c|c|c|c|}
\hline $\begin{array}{l}\text { Authors } \\
\text { (Ref.) } \\
\text { country }\end{array}$ & $\begin{array}{l}\text { Study } \\
\text { design }\end{array}$ & Sample size & ASD assessment & Sleep-wake cycle assessment & Results & Major limitations \\
\hline $\begin{array}{l}\text { Takase, Taira and } \\
\text { Sasaki (57) } \\
\text { Japan }\end{array}$ & $\begin{array}{l}\text { Cross-sectional } \\
\text { study }\end{array}$ & $\begin{array}{l}89 \text { autistic } \\
\text { children } \\
\text { (3-20 years). }\end{array}$ & Clinical diagnoses. & $\begin{array}{l}\text { Actigraphy } \\
\text { Total sleep time (TST) was calculated } \\
\text { from their sleep logs. }\end{array}$ & $\begin{array}{l}\text { One autistic girl showed a tendency of non-24-h } \\
\text { sleep-wake syndrome. The others did not. Most } \\
\text { subjects showed a large variation in TST. }\end{array}$ & $\begin{array}{l}\text { No diagnostic criteria } \\
\text { for diagnosis, no control } \\
\text { group. }\end{array}$ \\
\hline $\begin{array}{l}\text { Nicholas et al. (25) } \\
\text { Autism Genetic } \\
\text { Resource Exchange }\end{array}$ & $\begin{array}{l}\text { Cross-sectional } \\
\text { study }\end{array}$ & $\begin{array}{l}110 \text { autistic } \\
\text { subjects and their } \\
\text { parents. }\end{array}$ & $\begin{array}{l}\text { ADI-R, } \\
\text { ADOS-G94, } \\
\text { DSM-IV diagnostic } \\
\text { criteria. }\end{array}$ & $\begin{array}{l}\text { Analysis of the single-nucleotide } \\
\text { polymorphisms (SNPs) in } 11 \mathrm{clock} / \\
\text { clock-related genes. }\end{array}$ & $\begin{array}{l}\text { A significant allelic association was detected for } \\
\text { PER1 and NPAS2. }\end{array}$ & $\begin{array}{l}\text { Predominant high- } \\
\text { functioning subjects. }\end{array}$ \\
\hline $\begin{array}{l}\text { Giannotti et al. (58) } \\
\text { Rome, Italy }\end{array}$ & $\begin{array}{l}\text { Case-control } \\
\text { study }\end{array}$ & $\begin{array}{l}104 \text { children with } \\
\text { autism; } \\
162 \text { TD children. }\end{array}$ & $\begin{array}{l}\text { DSM-IV-TR } \\
\text { diagnostic criteria; } \\
\text { ADI-R; } \\
\text { ADOS-G; } \\
\text { CARS. }\end{array}$ & $\begin{array}{l}\text { CSHQ; } \\
\text { Parental report sleep diary for } 4 \text { weeks; } \\
21 \text { channel EEG recordings. }\end{array}$ & $\begin{array}{l}\text { Regressed group showed higher incidence of } \\
\text { circadian rhythm disorders than non-regressed } \\
\text { ones. The regressed group showed higher CSHQ } \\
\text { bedtime resistance, sleep onset delay, sleep } \\
\text { duration and night awakening scores. }\end{array}$ & $\begin{array}{l}\text { No evaluation of } \\
\text { sleep parameters by } \\
\text { standardized measures. }\end{array}$ \\
\hline $\begin{array}{l}\text { Mullegama et al. (59) } \\
\text { Richmond, VA, USA }\end{array}$ & $\begin{array}{l}\text { Cross-sectional } \\
\text { study }\end{array}$ & $\begin{array}{l}19 \text { children with } \\
\text { a molecular } \\
\text { diagnosis of del } \\
2 \text { 223.1 } \\
\text { ( } 9 \text { months to } 11 \\
\text { years). }\end{array}$ & $\begin{array}{l}\text { Molecular diagnosis } \\
\text { of del 2q23.1 }\end{array}$ & $\begin{array}{l}\text { Parent sleep questionnaire; } \\
\text { The expression of four circadian } \\
\text { genes, NR1D2, PER1, PER2, and } \\
\text { PER3, in 2q23.1 deletion syndrome } \\
\text { lymphoblastoid cell lines (LCLs). }\end{array}$ & $\begin{array}{l}\text { Molecular analysis of the circadian deficits } \\
\text { associated with haploinsufficiency of MBD5 in } \\
\text { which circadian gene mRNA levels of NR1D2, } \\
\text { PER1, PER2, and PER3 were altered in del 2q23.1 } \\
\text { of LCLs; haploinsufficiency of MBD5 can result in } \\
\text { dysregulation of circadian rhythm gene expression. } \\
\text { Circadian and mTOR signaling pathways were } \\
\text { associated with sleep disturbance. }\end{array}$ & $\begin{array}{l}\text { Small sample size; } \\
\text { no objective sleep } \\
\text { measures. }\end{array}$ \\
\hline $\begin{array}{l}\text { Yang et al. (26) } \\
\text { Tochigi, Japan }\end{array}$ & $\begin{array}{l}\text { Case-control } \\
\text { study }\end{array}$ & $\begin{array}{l}28 \text { ASD patients } \\
23 \text { controls } \\
\text { of Japanese } \\
\text { descent. }\end{array}$ & $\begin{array}{l}\text { DSM IV-TR } \\
\text { diagnostic criteria }\end{array}$ & $\begin{array}{l}\text { The coding regions of } 18 \text { canonical } \\
\text { clock genes and clock-controlled genes } \\
\text { were sequenced. }\end{array}$ & $\begin{array}{l}\text { The mutations p.S20R in NR1D1, p.H542R } \\
\text { in CLOCK, p.L473S in ARNTL2, p.A325T in } \\
\text { TIMELESS, p.S13T in ARNTL, and p.G24E in PER2 } \\
\text { were diagnosed in ASD. Mutations in circadian- } \\
\text { relevant genes affecting gene function were more } \\
\text { frequent in patients with ASD than in controls. }\end{array}$ & $\begin{array}{l}\text { Small sample size; } \\
\text { no objective sleep } \\
\text { measures. }\end{array}$ \\
\hline $\begin{array}{l}\text { Goto et al. (60) } \\
\text { Nagoya, Japan }\end{array}$ & $\begin{array}{l}\text { Case-control } \\
\text { study }\end{array}$ & $\begin{array}{l}111 \\
\text { Caucasian } \\
87 \\
\text { Japanese } \\
\text { patients with } \\
\text { ASD; } \\
158 \\
\text { Caucasian and } \\
133 \\
\text { Japanese TD } \\
\text { children. }\end{array}$ & $\begin{array}{l}\text { DSM IV-TR and } \\
\text { DSM-5 diagnostic } \\
\text { criteria. }\end{array}$ & $\begin{array}{l}\text { The patients, their siblings, and parents } \\
\text { were tested for mutations in all exons of } \\
\text { NR1D1 (also known as Rev-Erb } \alpha \text { ). }\end{array}$ & $\begin{array}{l}\text { They detected single-base changes with an amino } \\
\text { acid substitution in the coding region of NR1D1 in } \\
4 \text { individuals. Not detected in controls. c.1012C } \\
\text { were identified as the rare SNPs. A (p.R500H) } \\
\text { mutation (AU1098302) had typical features of ASD } \\
\text { and no difficulty in sleep induction; he showed } \\
\text { strong anxiety and little sociability without verbal } \\
\text { communication with others. }\end{array}$ & $\begin{array}{l}\text { No objective sleep } \\
\text { measures. }\end{array}$ \\
\hline
\end{tabular}




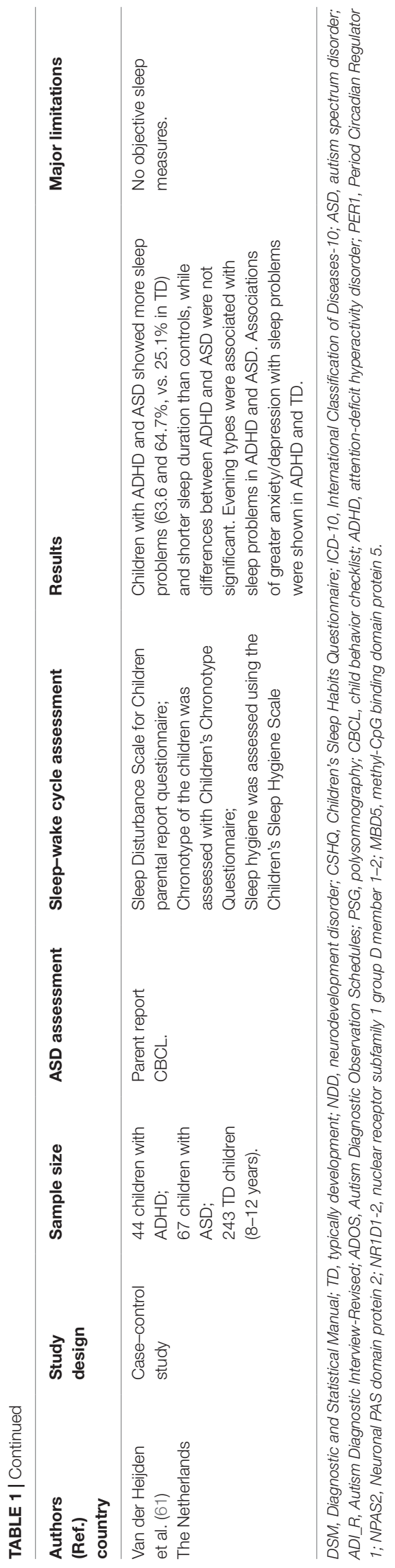

show sleeplessness with two specific circadian problems: phase delay of sleep periods and an irregular sleep-wake pattern. Some recent studies have investigated the genetic patterns of circadian rhythmicity in autistic subjects. First, Nicholas et al. (25) screened 110 individuals with ASD and their parents, analyzing the single-nucleotide polymorphisms (SNPs) in 11 clock/clockrelated genes. A significant allelic association was detected for Period Circadian Regulator 1 (PER1) and Neuronal PAS domain protein 2 (NPAS2) and ASD. A later study (59) described the circadian deficits in del 2q231 of lymphoblastoid cell lines (LCLs) in 19 ASD children with high prevalence of sleep disturbances. They found that circadian gene mRNA levels of NR1D2 (nuclear receptor subfamily 1 group D member 1), PER1, PER2, and PER3 were altered in del 2q23.1. Yang et al. (26) sequenced the coding regions of 18 canonical clock genes and clock-controlled genes in 28 ASD patients and 23 controls. They detected several mutations/SNPs in circadian-relevant genes affecting gene function in the ASD patients. Mutations in NR1D1, CLOCK, and ARNTL2 were detected only in individuals with ASD with sleep disorder. The most recent work (60) tested mutations in all exons of NR1D1 in 198 autistic subjects. They detected singlebase changes with an amino acid substitution in the coding region of NR1D1 in individuals with ASD. In summary, children with ASD show circadian and sleep rhythms alterations such as irregular and delayed sleep phase and several mutations in the expression of clock genes.

\section{Sleep Disturbances in Children With Autism Spectrum Disorder}

Sixty-five studies have been evaluated on the sleep pattern of children with ASD (Table 2), and some of them reported a prevalence rate of sleep disturbances between $64 \%$ and $93 \%$ $(65,71,95,108,109,114,125)$ underlining a great prevalence of sleep disturbances during early life $(62,63,65,86,109,125)$ with no gender differences $(62,89)$. In particular, total sleep time has shown to be reduced starting from 30 months of age toward adolescence $(98,104,107)$.

Researches based on parental reports and objective measurements (actigraphy and polysomnography) have suggested that autistic children are more likely to have sleep difficulties than children with other neurodevelopment disorder $(69,70,74,75$, $78,80,83,90,107)$ and children with normal development $(62$, $64,69,80,85,90,91,120)$. Among autistic subjects, some studies have reported that children with intellectual disabilities and/or with low levels of functioning may experience higher frequency of sleep disturbances $(58,62)$, while other studies have reported that high-functioning autistics may experience more sleep problems (shorter sleep duration, early night awakenings, and longer sleep latencies) than low-functioning children and control groups (63, 64). Some studies conducted in adolescents have also reported that those with high-functioning autism were three times more likely to have sleep problems than their peers with normal development (102). The most frequent sleep pattern observed across all the studies included the following: difficulties falling asleep $(63-65,72,78,89,91,109)$, restless sleep $(64,72)$, difficulties falling asleep in own beds with late bedtime $(58,104,119)$, 
TABLE 2 | Clinical studies on sleep disturbances in autism spectrum disorder in children

\begin{tabular}{|c|c|c|c|c|c|c|}
\hline $\begin{array}{l}\text { Authors } \\
\text { (Ref.) } \\
\text { country }\end{array}$ & Study design & Sample size & ASD assessment & $\begin{array}{l}\text { Sleep-wake cycle } \\
\text { assessment }\end{array}$ & Results & Major limitations \\
\hline $\begin{array}{l}\text { Hoshino et al. (62) } \\
\text { Fukushima Japan }\end{array}$ & Case-control study & $\begin{array}{l}75 \text { children with autism } \\
\text { ( } 3-15 \text { years); } \\
75 \text { TD children } \\
\text { ( } 3-11 \text { years). }\end{array}$ & $\begin{array}{l}\text { WHO and Kanner's } \\
\text { diagnostic criteria; } \\
\text { Infantile Developmental } \\
\text { Test. }\end{array}$ & $\begin{array}{l}\text { Sleep pattern was checked } \\
\text { by the parents day-to-day } \\
\text { for } 1 \text { month. }\end{array}$ & $\begin{array}{l}65 \% \text { of autistic children showed sleep } \\
\text { disturbance, no gender differences. } \\
\text { Poorly developed autistic children showed } \\
\text { a higher rate of sleep disturbance vs. well- } \\
\text { developed autistic children. }\end{array}$ & $\begin{array}{l}\text { No psychometric } \\
\text { assessment of sleep } \\
\text { pattern. }\end{array}$ \\
\hline $\begin{array}{l}\text { Richdale and Prior } \\
\text { (63) } \\
\text { Australia }\end{array}$ & Case-control study & $\begin{array}{l}39 \text { children with autism } \\
\text { (32 months-19 years): } \\
\text { IQ }<55 \text { (low-functioning, } \\
N=12 \text { ) vs. } I Q>55 \text { (higher- } \\
\text { functioning, } N=27 \text { ) } \\
35 \text { TD children. }\end{array}$ & $\begin{array}{l}\text { DSM-III diagnostic criteria. } \\
\text { IQ: Leiter International } \\
\text { Performance Scale or } \\
\text { Bayley Infant Development } \\
\text { Scales or Mertill-Palmer } \\
\text { Scale of Mental Tests. }\end{array}$ & $\begin{array}{l}\text { Parents completed } \\
\text { 14-day sleep diaries and } \\
\text { questionnaires. }\end{array}$ & $\begin{array}{l}\text { During childhood, most of the children with } \\
\text { autism experienced sleep problems: extreme } \\
\text { sleep latencies, lengthy periods of night } \\
\text { awakening, shortened night sleep, and early } \\
\text { morning waking. }\end{array}$ & $\begin{array}{l}\text { Small sample size; } \\
\text { no evaluation of } \\
\text { sleep parameters } \\
\text { with standardized } \\
\text { assessment. }\end{array}$ \\
\hline $\begin{array}{l}\text { Patzold et al. (64) } \\
\text { Australia }\end{array}$ & Case-control study & $\begin{array}{l}31 \text { children with autism; } 36 \text { TD } \\
\text { children. }\end{array}$ & $\begin{array}{l}\text { DSM-III or DSM-III-R } \\
\text { diagnostic criteria. }\end{array}$ & $\begin{array}{l}\text { A sleep diary completed } \\
\text { by parents over a } \\
\text { 2-week period; behaviors } \\
\text { questionnaires. }\end{array}$ & $\begin{array}{l}\text { Children with autism were likely to fall asleep } \\
\text { later at night, have longer sleep latencies, } \\
\text { sleep less at night, and spend a significant } \\
\text { period of time awake during the night, } \\
\text { compared with control group. }\end{array}$ & $\begin{array}{l}\text { Small sample size; } \\
\text { No evaluation of } \\
\text { sleep parameters } \\
\text { by standardized } \\
\text { assessment. }\end{array}$ \\
\hline $\begin{array}{l}\text { Taira, Takase and } \\
\text { Sasaki (65) } \\
\text { Japan }\end{array}$ & $\begin{array}{l}\text { Cross-sectional } \\
\text { study }\end{array}$ & 88 children with autism. & Clinical diagnosis. & Sleep questionnaires. & $\begin{array}{l}\text { Sleep disorders were observed in } 56 \text { children, } \\
44 \text { of whom had sleep disorders before } 3 \\
\text { years old. The most common problem was } \\
\text { difficulty falling asleep, frequent awakening } \\
\text { during sleep time, early morning awakening. }\end{array}$ & $\begin{array}{l}\text { No control group; } \\
\text { no evaluation of } \\
\text { sleep and autism } \\
\text { with standardized } \\
\text { assessment. }\end{array}$ \\
\hline $\begin{array}{l}\text { Diomedi et al. (66) } \\
\text { Roma, Italy }\end{array}$ & $\begin{array}{l}\text { Cross sectional } \\
\text { study }\end{array}$ & $\begin{array}{l}10 \text { mentally retarded autistic } \\
\text { subjects ( } 12-24 \text { years); } \\
8 \text { Down syndrome subjects; } \\
8 \text { TD subjects. }\end{array}$ & $\begin{array}{l}\text { DSM-IV diagnostic criteria; } \\
\text { CARS; } \\
\text { Psychological Educational } \\
\text { Profile (PEP). }\end{array}$ & $\begin{array}{l}\text { Two consecutive overnight } \\
\text { PSG. }\end{array}$ & $\begin{array}{l}\text { Compared to normal subjects, autistic } \\
\text { subjects presented a significant reduction } \\
\text { of REM \%, a fragmentation of REM periods, } \\
\text { due to a frequent intrusion of NREM } 1 \text { and } 2 \text {, } \\
\text { an increased number of awakenings with a } \\
\text { consequent reduction of Sleep Efficiency. }\end{array}$ & Small sample size. \\
\hline $\begin{array}{l}\text { Hering et al. (67) } \\
\text { Israel }\end{array}$ & Comparative study & $\begin{array}{l}22 \text { children with autism: } \\
12 \text { with sleep problems }\end{array}$ & Clinical diagnosis. & $\begin{array}{l}\text { Sleep questionnaire; } 72 \mathrm{~h} \text { of } \\
\text { actigraphy. }\end{array}$ & $\begin{array}{l}\text { Autistic children showed early morning } \\
\text { awakenings and multiple and night arousals }\end{array}$ & $\begin{array}{l}\text { Small sample size; } \\
\text { no evaluation of } \\
\text { autism parameters } \\
\text { by standardized } \\
\text { assessment. }\end{array}$ \\
\hline $\begin{array}{l}\text { Godbout et al. (68) } \\
\text { Canada }\end{array}$ & Case-control study & $\begin{array}{l}8 \text { patients with AS ( } 7-53 \\
\text { years); } 8 \text { TD age-/sex-matched } \\
\text { subjects. }\end{array}$ & $\begin{array}{l}\text { DSM-IV diagnostic criteria; } \\
\text { ADI. }\end{array}$ & $\begin{array}{l}\text { Sleep was recorded for two } \\
\text { consecutive nights. }\end{array}$ & $\begin{array}{l}\text { Patients with AS showed decreased sleep } \\
\text { time in the first } 2 / 3 \text { of the night, increased } \\
\text { number of shifts into REM sleep from waking, } \\
\text { and REM sleep disruption; sleep spindles } \\
\text { were significantly decreased. }\end{array}$ & $\begin{array}{l}\text { Small sample size; } \\
\text { use of medications. }\end{array}$ \\
\hline
\end{tabular}




\begin{tabular}{|c|c|c|c|c|c|c|}
\hline $\begin{array}{l}\text { Authors } \\
\text { (Ref.) } \\
\text { country }\end{array}$ & Study design & Sample size & ASD assessment & $\begin{array}{l}\text { Sleep-wake cycle } \\
\text { assessment }\end{array}$ & Results & Major limitations \\
\hline $\begin{array}{l}\text { Elia et al. (69) } \\
\text { Italy }\end{array}$ & Comparative study & $\begin{array}{l}17 \text { children and adolescents } \\
\text { with ASD ( } 5-16 \text { years); } \\
7 \text { patients with mental } \\
\text { retardation and fragile } X \\
\text { syndrome; } 5 \text { TD subjects. }\end{array}$ & $\begin{array}{l}\text { DSM-IV diagnostic } \\
\text { criteria; karyotyping; } \\
\text { neurometabolic } \\
\text { screenings; brain imaging; } \\
\text { Psychoeducational Profile- } \\
\text { revised test (PEP-R); } \\
\text { CARS. }\end{array}$ & $\begin{array}{l}\text { Two overnight PSG with one } \\
\text { adaptation night. }\end{array}$ & $\begin{array}{l}\text { Density of REM was not significantly different } \\
\text { in the three groups; some sleep parameters } \\
\text { such as time in bed, and total sleep time were } \\
\text { significantly lower in ASD subjects than in TD } \\
\text { ones; CARS scores to visual response and } \\
\text { nonverbal communication showed significant } \\
\text { correlation with some sleep parameters. }\end{array}$ & Small sample size. \\
\hline $\begin{array}{l}\text { Honomichl et al. } \\
\text { (70) } \\
\text { California }\end{array}$ & Longitudinal study & 100 children with PDD & $\begin{array}{l}\text { Children were diagnosed } \\
\text { with ASD, PDD not } \\
\text { otherwise specified, AS, } \\
\text { or other related disorders. }\end{array}$ & $\begin{array}{l}\text { Two sleep diary data } \\
\text { collection periods; } \\
\text { CSHQ; Parenting Events } \\
\text { Questionnaire. }\end{array}$ & $\begin{array}{l}\text { All children with PDD exhibited longer sleep } \\
\text { onset and greater fragmentation of sleep than } \\
\text { that reported for age-matched community } \\
\text { norms. }\end{array}$ & \\
\hline $\begin{array}{l}\text { Wiggs and Stores } \\
\text { (71) } \\
\text { Oxford, UK }\end{array}$ & $\begin{array}{l}\text { Cross-sectional } \\
\text { study }\end{array}$ & $\begin{array}{l}69 \text { children with ASD (aged } 5 \\
\text { to } 16 \text { years). }\end{array}$ & ICD-10 diagnostic criteria. & $\begin{array}{l}\text { Sleep histories from parents; } \\
\text { Simonds and Parraga Sleep } \\
\text { Questionnaire; 2-week sleep } \\
\text { diary; actigraphy for five } \\
\text { nights. }\end{array}$ & $\begin{array}{l}\text { Parent-reported sleeplessness (64\%). Sleep } \\
\text { disorders underlying the sleeplessness } \\
\text { were most commonly behavioral; sleep } \\
\text { patterns measured objectively did not differ } \\
\text { between those children with or without } \\
\text { reported sleeplessness, but the sleep quality } \\
\text { of all children seemed to be compromised } \\
\text { compared with normal values. }\end{array}$ & $\begin{array}{l}\text { Sample included } \\
\text { children of various } \\
\text { ages and intellectua } \\
\text { levels. }\end{array}$ \\
\hline $\begin{array}{l}\text { Gail Williams, P } \\
\text { et al. (72) } \\
\text { England }\end{array}$ & $\begin{array}{l}\text { Cross-sectional } \\
\text { study }\end{array}$ & 210 children with autism. & $\begin{array}{l}\text { DSM-IV diagnostic criteria; } \\
\text { Wechsler Intelligence } \\
\text { Scale for Children, 3ed; } \\
\text { Differential Ability Scales } \\
\text { Mental Retardation (MR). }\end{array}$ & $\begin{array}{l}\text { Likert-based questionnaire } \\
\text { for parent report. }\end{array}$ & $\begin{array}{l}\text { Sleep problems reported: difficulty in } \\
\text { falling asleep, restless sleep, not falling } \\
\text { asleep in own bed, and frequent wakings, } \\
\text { sleepwalking, morning headaches, crying } \\
\text { during sleep, apnea, and nightmares. No } \\
\text { significant differences were identified in } \\
\text { frequencies of reported sleep problems } \\
\text { between MR and not MR groups. }\end{array}$ & $\begin{array}{l}\text { No evaluation of } \\
\text { sleep parameters by } \\
\text { objective measures. }\end{array}$ \\
\hline $\begin{array}{l}\text { Schreck et al. (73) } \\
\text { USA }\end{array}$ & $\begin{array}{l}\text { Cross-sectional } \\
\text { study }\end{array}$ & $\begin{array}{l}55 \text { children with autism (5-12 } \\
\text { years). }\end{array}$ & $\begin{array}{l}\text { Gilliam Autism Rating } \\
\text { Scale (GARS). }\end{array}$ & $\begin{array}{l}\text { Parental report sleep } \\
\text { questionnaire. }\end{array}$ & $\begin{array}{l}\text { Children with strong responses to the } \\
\text { environment at night and who tend to awaken } \\
\text { at night show more markedly autistic-type } \\
\text { communication patterns on the GARS. }\end{array}$ & $\begin{array}{l}\text { No evaluation of } \\
\text { sleep parameters by } \\
\text { objective measures. }\end{array}$ \\
\hline $\begin{array}{l}\text { Polimeni et al. (74) } \\
\text { Australia }\end{array}$ & $\begin{array}{l}\text { Cross-sectional } \\
\text { study }\end{array}$ & $\begin{array}{l}53 \text { children with autism; } \\
53 \text { children with AS; } 66 \text { TD } \\
\text { children. }\end{array}$ & Clinical diagnosis. & $\begin{array}{l}\text { The Behavioral Evaluation of } \\
\text { Disorders of Sleep (BEDS). }\end{array}$ & $\begin{array}{l}\text { High prevalence of sleep problems with } \\
\text { significantly more problems reported in the } \\
\text { autism and AS groups. }\end{array}$ & $\begin{array}{l}\text { No evaluation of } \\
\text { sleep and autism } \\
\text { parameters by } \\
\text { standardized } \\
\text { measures; use of } \\
\text { medication. }\end{array}$ \\
\hline $\begin{array}{l}\text { Cotton \& Richdale } \\
\text { (75) } \\
\text { Australia }\end{array}$ & Case-control study & $\begin{array}{l}153 \text { children: } 98 \text { had an ID, } \\
37 \text { with autism, } 15 \text { with Down } \\
\text { syndrome, } 29 \text { with Prader- } \\
\text { Willi syndrome, and } 29 \text { with } \\
\text { intellectual disability; } 55 \text { TD } \\
\text { subjects. }\end{array}$ & Clinical diagnosis. & $\begin{array}{l}\text { Parental report sleep } \\
\text { questionnaire. }\end{array}$ & $\begin{array}{l}\text { Sleep problems were more prevalent in autism } \\
\text { than the other disorders. Sleep maintenance } \\
\text { problems were common in autism. }\end{array}$ & $\begin{array}{l}\text { Small sample size; } \\
\text { no evaluation of } \\
\text { sleep and autism } \\
\text { parameters by } \\
\text { standardized } \\
\text { measures. }\end{array}$ \\
\hline
\end{tabular}
Differential Ability Scales

Gilliam Autism Rating

55 children with autism (5-12 53 children with autism 53 children with AS; 66 TD

153 children: 98 had an ID, syndrome, 29 with Praderintellectual disability: 55 TD subjects. 
assessment

Allik et al. (76)

Stockholm,

Case-control study

32 school-age children with AS and HFA; 32 TD age- and

Sweden

Allik et al. (77)

Stockholm,

Case-control study

Sweden

Krakowiak et al.

(78)

California

Liu et al. (79)

USA

Comparative study

108 children with ASD, 27 children with AS; 32 with other diagnoses of ASD.

32 school-age children with AS and HFA; 32 TD age-/gendermatched children

303 children with ASD 63 children with other developmental delays (DD);

163 TD children. The mean age was 3.6 years.
Clinical diagnosis; ASSQ.

Parent-Reported Sleep Problems; 1-week parent recorded Child Sleep Diary; 1-week actigraphy.

Clinical diagnosis; ASSQ; Parent-reported sleep and adaptive functioning was assessed with specific scales.

Parent-administered questionnaire.

problems; 1-week parentrecorded Child Sleep Diary 1 -week actigraphy.

Parental report diagnosis of ASD; ADOS-G.

\section{CSHQ; A structured sleep} and family demographic questionnaire.

SHQ; sleep histories;

21 children with ASD; 10 TD children (4-10 years).
DSM-IV-TR diagnostic criteria; Clinical diagnosis; ADOS; CBCL; Peabody Picture Vocabulary Test (PPVT).
Parental report, sleep diary, and actigraphy showed that children in the AS/HFA group spent longer time awake in bed before falling asleep than the control group.

Parent-reported difficulties initiating sleep and daytime sleepiness were more common in children with AS/HFA than in controls. Children with insomnia showed more parentreported autistic and emotional symptoms, and more teacher-reported emotional and hyperactivity symptoms than those without insomnia.

$53 \%$ of children with ASD showed at least one sleep problem, followed by $46 \%$ of children with DD, and $32 \%$ of the

TD group. Children with ASD had higher problems with sleep onset and higher night awakening compared to the TD group. Sleep disturbances of ASD group were not associated with cognitive and/or adaptive delays.

$86 \%$ of children had at least one sleep problem almost every day, including 54\% with bedtime resistance, $56 \%$ with insomnia, $53 \%$ with parasomnias, $25 \%$ with sleep disordered breathing, $45 \%$ with morning rise problems, and $31 \%$ with daytime sleepiness. Individual sleep problems: restless during sleep (28.7\%), difficulty falling asleep (28.1\%), awakened by others in the morning (26.9\%), bed-wetting $(26.3 \%)$, and poor appetite in the morning (25.7\%).

Poor sleepers showed prolonged sleep latency and decreased sleep efficiency on night 1 of PSG and differed on insomniarelated subscales of the CSHQ (increased sleep onset delay and decreased sleep duration) and also affective and reciprocal social problems on the $\mathrm{CBCL}$ and the ADOS, respectively.
Small sample size; use of medication.

Small sample size: use of medication.

No evaluation of sleep parameters by standardized

measures.

Lack of a control group.

Small sample size. monitoring combined with EEG and PSG. 


\section{(Ref.)}

Miano et al. (81)

Italy

Case-control study

31 patients with ASD: 17 with I.Q. 25-40 4 with I.Q. 40-55 (3.7-19 years); 893 TD children and adolescents. criteria; CARS; Wechsler Intelligence Scale for Children Revised or Weschsler Adult Intelligence Scale.

Bruni et al. (82) Cross-sectional study

8 children with AS; 10 children with autism, 12 TD children.

ADOS; CBCL; Wechsler Intelligence Scale for Children-Third Edition Revised-WISC-III

DeVincent et al. Case-control study
(83)

New York

Dominick et al. (84) Retrospective

USA

study

Case-control study

Allik et al. (85)

Stockholm,

Sweden
112 children with PDD (49 DSM-IV diagnostic

with autistic disorder, 13 with

$\mathrm{AS}$, and 50 with PDD-not

otherwise specified); 497 TD

children.

39 children with a history of

language impairment (HLI);

67 children with ASD. and HFA; 16 TD age-/gendermatched children. criteria; Early Childhood

Inventory-4; ADOS.

$D S M-I V$ diagnostic criteria;

ADI-R; ADOS-G.
The Atypical Behavior

Patterns Questionnaire-

parental reported.
Questionnaire;

Pediatric Daytime Sleepiness Scale; PSG

Early Childhood Inventory-4.

t

(

ASD children showed high prevalence of initiating and maintaining sleep problems, enuresis, repetitive behavior when falling asleep, daytime sleepiness. PSG: ASD children showed reduced time in bed, total sleep time, sleep period time and REM

latency.

AS children showed high prevalence of initiating and maintaining sleep problems and daytime sleepiness. Subjects with AS showed increased CAP rate in SWS and A1 percentage. In subjects with AS, verbal IQ had a significant positive correlation with total CAP rate and CAP rate in SWS and with global and SWS A1 index. The percentage of A2 negatively correlated with full-scale $I Q$, verbal and performance IQ. CBCL total score correlated positively with CAP rate and A1 index while externalizing score correlated negatively with $\mathrm{A} 3 \%$.

$18 \%$ of children with PDD met the criteria for disturbance. There were no significant Ifferences between PDD subtypes in either he rate or severity of sleep problem. Sleepdisturbed children in both samples exhibited more severe behavioral difficulties than

children without sleep problems.

Over 2/3 of the children with autism experienced atypical patterns of sleep. Initial insomnia and middle insomnia each occurred in $>50 \%$ of the children with ASD. $12 \%$ of the sleep-disturbed children with ASD have terminal insomnia. The presence of sleep disturbances in children with autism and with $\mathrm{HLI}$ combined was significantly related to the presence of depression.

16 school-age children with AS Clinical diagnosis. 1-week actigraphy.
At follow-up (2-3 years after the baseline) children with AS/HFA showed longer night waking and lower sleep efficiency during weekends than the controls.
Small sample size.

No evaluation of

sleep parameters by objective measures.

Use of retrospective questionnaire;

interviewers

were not blind to the participant's diagnosis; sample

was not chosen at random.

Small sample size; use of medication. 
68 children with autism; 57 children with developmental

Goodlin-Jon

Comparative study

et al. (86)

California

delay without autism (DD):

69 TD children (2.0-5.5 years).

ADOS; Test of cognitive

ability and of adaptive

functioning; ADI-R.

Actigraphy; sleep diary;

CSHQ.

group after sleep onset exhibited more and longer awakenings than the other two groups. Autistic children exhibited less total sleep time/24 $\mathrm{h}$ than the other two groups. Parent reports of sleep problems were higher in the AUT and DD groups than the TD group, but parent reports did not concur with more objective measures for behavioral insomnia.
ADOS; Test of cognitive Children were studied on ability and of adaptive functioning; ADI-R. delay without autism [DD]: 69 TD children (2.0-5.5 years).

et al. $(87)$

Comparative study

\section{Goodlin-Jones \\ et al. (88)}

Comparative study

68 children with autism, 57 children with developmental delay without autism [DD]; 69 TD children (2.0-5.5 years)

by a 3-month interval.

At each assessment:

actigraphy for 1 week; sleep-wake diaries; CSHQ.

Mullen Scales of Early Learning; Vineland Adaptive Behavior

Actigraphy; sleep diary:
Paavonen $\mathrm{J}$ et al. (89) Finland

Souders et al. (90) Descriptive crossPhiladelphia, PA sectional study.
Both neurodevelopmental groups showed chee occasions, separated Social Communication Questionnaire.

DSM-IV or ICD-10 diagnostic criteria; $\mathrm{CBCL}$ ASSQ.

CSHQ; 17-day parental report sleep diaries: 10-nights of actigraphy. actigraphic records.

CSHQ was clinically useful for screening of sleep problems in TD young children as well as in children with diverse

neurodevelopmental diagnoses; sleep

TD; the risk for sleep onset problems was vs. TD.

$66.1 \%$ of parents of children with ASD and $45 \%$ of parents of the control group more sleep problem by actigraphy and the
59 children with ASD (26 with autism, 21 with PDD-NOS, and 12 with AS) (4-10 years); 40 TD subjects
DSM-IV-TR diagnostic criteria; ADOS; Children enrolled as TD were screened with Social Communication

Questionnaire (SCQ) and developmental history.
CSHQ than TD children. Sleep onset insomnia and night awakenings decreased respectively by $40 \%$ and $30 \%$ every 3 -month periods of problems were prevalent in young children.

Problems with sleep onset and maintenance, sleep-related fears, negative attitudes toward sleeping, and daytime somnolence were more frequent in AS vs. TD. Short sleep duration was almost twofold (59\% vs. $32 \%$ ) in AS vs.

fivefold (53\% vs. $10 \%$ ) more common in AS reported sleep problems in their sons; $66.7 \%$ of children with ASD (75\% autism, 52.4\%

PDD-NOS, $75 \%$ AS) and $45.9 \%$ of the control sample size subjects had disturbed sleep by actigraphy.
No evaluation of sleep parameters by standardized measures; small

Results may not generalize to a more heterogeneous population-based, community sample or to children referred for a clinical sleep disorder. The CSHQ has not been validated for these ages.

No evaluation of sleep parameters by standardized measures. 
Goldman et al. (91) Nashville, TN

Case-control study

42 children with ASD without intellectual disability (4 to 10 years); 16 age-compared TD children.

Buckley et al. (92) New York

Comparative study

60 children with autism; 13 children with developmental delay; 15 children with TD (2-13 years)

Giannotti et al. (93) Rome, Italy

Comparative study 22 children with non-regressive autism; 18 children with regressive autism; 12 TD children (5-10 years). criteria; ADI-R; ADOS-G;

nonverbal IQ > 50 assessed by Leiter International Performance Scale.

$D S M-I V-T R$ diagnostic criteria ADOS; Repetitive Behavior Scales-Revised (RBS-R); Peabody (PPVT-III).

ADOS; ADI-R.

\section{ADOS; ADI-R.}

187 children with ID and/or ASD.

68 children with autism; 57 children with DD; 69 TD children (24-66 months).

\section{ADOS; Developmental,}

Dimensional and

Diagnostic Interview (3DI).

ADOS; ADI-R; Mullen Scales of Early Learning (MSEL); General adaptive behavior scales.

$$
\text { CSHQ; PSG. }
$$

CSHQ; Parental Concerns Questionnaire (PCQ); $\mathrm{CBCL}$ : Actigraphy: PSG.

SHQ; PSG.

CSHQ; an overnight PSG.

ASD poor sleepers differed from ASD good sleepers on actigraphy (sleep latency, sleep efficiency, fragmentation) and PSG (sleep latency) measures, reporting inattention, hyperactivity, and restricted/repetitive behaviors. Fragmentation was correlated with more restricted/repetitive behaviors.

No differences between TD vs. developmental delay groups. Comparison of autistic children vs. TD children revealed short total sleep time, great slow-wave sleep percentage, and small REM sleep percentage ( $14.5 \%$ vs. $22.6 \%$ ) in ASD ones.

Regressed children reported high CSHQ score: bedtime resistance, sleep onset delay, sleep duration and night wakings. Regressive subjects had significantly less efficient sleep, less total sleep time, prolonged sleep latency, prolonged REM latency and more time awake after sleep onset than non-regressive and TD group.

Actigraphy for 7 consecutive days for each of the 3 recording weeks (initial evaluation, 3 months later and again after 3 months) During each 7-day week, parents completed a daily sleep diary.

CSHQ; Spence Children's Anxiety Scale-Parent Version (SCAS-P); Aberrant Behaviour ChecklistCommunity (ABC-C).

7 consecutive 24-h periods of actigraphy; parent-report sleep-wake diary. Sleep was assessed for 7 consecutive days on 3 separate occasions over 6 months.
ASD group slept less per 24-h period and were less likely to awaken at night than children in the other two groups. Children in the DD group had more frequent and longer duration nighttime awakenings than children in the ASD group. Children in the two neurodevelopmentally disordered groups demonstrated more night-to-night variability in their sleep-wake measures than children in the TD group.

Significant positive correlations between sleep problems, challenging behaviors and anxiety in children with ID and/or ASD.

Children with autism napped less often and for shorter periods of time than children

with DD Children with DD napped more like children in the TD group, who were 6 months younger. Each group displayed an expected matured out of their naps. shift in daytime sleep as more children
Parental measures to differentiate the poor and the good sleepers groups; small sample size.

Use of medications.

Small sample size; no evaluation of sleep parameters by standardized measures; small sample size.

No evaluation of sleep parameters by standardized measures; small sample size

Lack of specific groups of intellectual disability. 
68 children with autism (AUT); 57 children with DD without

Anders et al. (97)

Case-control study AUT; 69 TD children.

Goldman et al. (98) USA

Cross-sectional study

Cross-sectional study

Colorado

1,859 children of the Autism Treatment Network

1193 children with ASD.
Siversten et al. (101) Longitudinal study Norway

Baker et al. (102) Australia
Comparative study 34 adolescents with HFASD (14-17 years); 27 TD adolescents.
ADOS; ADI-R;

Psychoeducational

Profile-Revised (PEP-R) Bayley pegboard task CBCL.

eneral adaptive behavio scales; Survey Interview

Form, Second Edition;

$\mathrm{CBCL}$

General adaptive behavio scales. sleep disorders sleep diary. Questionnaire.

\section{CSHQ.}

3700 children, of whom 28 have ASD.

SSQ

Parent-reported sleep

Social Communication Questionnaire.
7 consecutive 24-h periods of actigraphy for each of the 3 recording weeks (initial evaluation, 3 months later and again after 3 months). During each 7-day week, parents completed a daily

CSHQ; Parents Concerns Difficulties Questionnaire (SDQ).

Both autism and ID groups showed poorer daytime performance and behaviors than the TD one. These significant differences persisted over 6 months; long night awakenings and lower sleep efficiency predicted daytime sleepiness in the ID group parent-report sleep problems were associated with daytime sleepiness and behavior problems.

Adolescents reported delayed sleep onset, short sleep duration, and daytime sleepiness; while toddlers reported bedtime resistance, sleep anxiety, parasomnias, and night wakings.

ASD group with sleep problems showed internalizing and externalizing behavior problems, and poor adaptive skill development. Children with moderate to severe sleep problems had greater behavior difficulties.

Children who slept fewer hours per night had lower overall intelligence, verbal skills, overall adaptive functioning, daily living skills, socialization skills, and motor development.

Children who slept fewer hours at night with waking during the night had more communication problems. Breathing-related sleep problems and fewer hours of sleep related most often to problems with perceptual tasks.

In the ASD group, the prevalence of chronic insomnia was more than 10 times higher compared to controls. ASD was a strong predictor of sleep problems and emotional and behavioral problems explained a large proportion of this association.

7-day sleep diary; actigraphy - Adolescents with HFASD were 3 times more in $55 \%$ of adolescents with HFASD; Sleep Habits Survey, adapted from the School Sleep Habits Survey: Pediatric daytime sleepiness scale; flinders fatigue scale. likely to report a sleep problem than their TD peers (46.2\% vs. $14.8 \%)$. Adolescents with HFASD had decreased sleep efficiency, and more fatigue compared with TD adolescents. While TD adolescents generally experienced one symptom of insomnia, adolescents with HFASD were likely to experience 2 or 3 symptoms of insomnia.
No developmentally tests of daytime functioning valid for NDD and TD preschool-age children.

No evaluation of sleep parameters by standardized measures.

No evaluation of sleep parameters by objective measures.

No evaluation of sleep parameters by objective measures; no measure of the severity of the sleep problems.

Small sample size. 


\begin{tabular}{|c|c|c|c|c|c|c|}
\hline $\begin{array}{l}\text { Authors } \\
\text { (Ref.) } \\
\text { country }\end{array}$ & Study design & Sample size & ASD assessment & $\begin{array}{l}\text { Sleep-wake cycle } \\
\text { assessment }\end{array}$ & Results & Major limitations \\
\hline $\begin{array}{l}\text { Hollway et al. (103) } \\
\text { USA }\end{array}$ & $\begin{array}{l}\text { Cross-sectional } \\
\text { study }\end{array}$ & $\begin{array}{l}1583 \text { children in the Autism } \\
\text { Treatment Network (2-17 } \\
\text { years). }\end{array}$ & $\begin{array}{l}\text { DSM-IV diagnostic criteria; } \\
\text { ADOS;CBCL; Mullen } \\
\text { Scales of Early Learning } \\
\text { (MSEL); Stanford-Binet } \\
\text { Intelligence Scale: Fifth } \\
\text { Edition. }\end{array}$ & $\begin{array}{l}\text { Short Sensory Profile; } \\
\text { CSHQ. }\end{array}$ & $\begin{array}{l}\text { Anxiety, autism symptoms severity, sensory } \\
\text { sensitivities, and GI problems were associated } \\
\text { with sleep disturbances. IQ positively } \\
\text { predicted sleep disturbance and children with } \\
\text { AS were more vulnerable than others. }\end{array}$ & $\begin{array}{l}\text { No evaluation of } \\
\text { sleep parameters by } \\
\text { objective measures. }\end{array}$ \\
\hline $\begin{array}{l}\text { Humphreys et al. } \\
\text { (104) } \\
\text { UK }\end{array}$ & $\begin{array}{l}\text { Cross-sectional } \\
\text { study }\end{array}$ & $\begin{array}{l}30 \text { children with classical } \\
\text { childhood autism; } 15 \text { children } \\
\text { with atypical autism; } 23 \text { children } \\
\text { with AS. }\end{array}$ & $\begin{array}{l}\text { Social Communication } \\
\text { Disorders Checklist; } \\
\text { Wechsler Intelligence } \\
\text { Scale for Children 3rd } \\
\text { edition (WISC-III). }\end{array}$ & $\begin{array}{l}\text { Parental report sleep } \\
\text { questionnaires. }\end{array}$ & $\begin{array}{l}\text { From aged } 30 \text { months to } 11 \text { years old, } \\
\text { children with ASD slept for } 17-43 \text { min less } \\
\text { each day than contemporary controls. No } \\
\text { significant difference in total sleep duration } \\
\text { was found in infancy, but from } 30 \text { months } \\
\text { of age, children with ASD slept less than } \\
\text { their peers. Nighttime sleep duration was } \\
\text { shortened by later bedtimes and earlier } \\
\text { waking times. }\end{array}$ & $\begin{array}{l}\text { Small sample size; } \\
\text { absence of a control } \\
\text { group. }\end{array}$ \\
\hline $\begin{array}{l}\text { Nadeau et al. (105) } \\
\text { USA }\end{array}$ & $\begin{array}{l}\text { Cross-sectional } \\
\text { study }\end{array}$ & $\begin{array}{l}102 \text { children and adolescents } \\
\text { with ASD and comorbid } \\
\text { anxiety disorders (7-16 years). }\end{array}$ & $\begin{array}{l}\text { ADI-R; ADOS; Social } \\
\text { Responsiveness Scale } \\
\text { (SRS) measuring severity } \\
\text { of autism spectrum } \\
\text { symptoms; Anxiety } \\
\text { Disorders Interview } \\
\text { Schedule; Pediatric } \\
\text { Anxiety Rating Scale; } \\
\text { Multidimensional Anxiety } \\
\text { Scale for Children-Parent; } \\
\text { report measuring of } \\
\text { anxiety symptoms. }\end{array}$ & CBCL. & $\begin{array}{l}\text { The number of sleep-related problems } \\
\text { endorsed directly associated with parent } \\
\text { ratings of social deficits, internalizing } \\
\text { and externalizing symptoms, and anxiety } \\
\text { symptoms, as well as with clinician-rated } \\
\text { anxiety symptoms. }\end{array}$ & $\begin{array}{l}\text { No evaluation of } \\
\text { sleep parameters by } \\
\text { objective measures; } \\
\text { absence of a control } \\
\text { group. }\end{array}$ \\
\hline $\begin{array}{l}\text { Richdale et al. (106) } \\
\text { Australia }\end{array}$ & Case-control study & $\begin{array}{l}27 \text { adolescents with HFASD } \\
\text { (14-17 years); } 27 \text { age-/sex- } \\
\text { matched TD adolescents } \\
\text { (14-17 years). }\end{array}$ & $\begin{array}{l}\text { The Centre for } \\
\text { Epidemiological studies } \\
\text { Depression scale; the } \\
\text { anxiety subscale of the } \\
\text { Depression, Anxiety and } \\
\text { Stress Scale. }\end{array}$ & $\begin{array}{l}\text { 7-day sleep/wake diary. } 55 \% \\
\text { of HFASD adolescents and } \\
\text { all TD adolescents wore an } \\
\text { actigraphy concurrently with } \\
\text { the sleep diary. Sleep Habits } \\
\text { Survey; Chronic Sleep } \\
\text { Reduction Questionnaire; } \\
\text { Sleep Anticipatory Anxiety } \\
\text { Questionnaire (SAAQ) to } \\
\text { measure pre-sleep arousal. }\end{array}$ & $\begin{array}{l}\text { Adolescents with HFASD had significantly } \\
\text { higher scores for sleep arousal compared } \\
\text { with TD adolescents, and poorer daytime } \\
\text { functioning. There were significant correlations } \\
\text { between sleep variables and psychopathology } \\
\text { variables the HFASD group, than in the TD } \\
\text { group. }\end{array}$ & Small sample size. \\
\hline $\begin{array}{l}\text { Hodge et al. (107) } \\
\text { San Bernardino, } \\
\text { CA }\end{array}$ & Comparative study & $\begin{array}{l}108 \text { children with ASD; } 108 \text { TD } \\
\text { children ( } 3-18 \text { years). }\end{array}$ & $\begin{array}{l}\text { Clinical diagnoses; Autism } \\
\text { Index; Gilliam Autism } \\
\text { Rating Scale-2. }\end{array}$ & CSHQ. & $\begin{array}{l}\text { Poor sleep quantity and quality in children } \\
\text { with ASD, particularly children aged 6-9 } \\
\text { years. The sleep problems of children with } \\
\text { ASD were unlikely to diminish with age. }\end{array}$ & \\
\hline
\end{tabular}




\begin{tabular}{|c|c|c|c|c|c|c|}
\hline $\begin{array}{l}\text { Authors } \\
\text { (Ref.) } \\
\text { country }\end{array}$ & Study design & Sample size & ASD assessment & $\begin{array}{l}\text { Sleep-wake cycle } \\
\text { assessment }\end{array}$ & Results & Major limitations \\
\hline $\begin{array}{l}\text { Tudor et al. (108) } \\
\text { USA }\end{array}$ & $\begin{array}{l}\text { Cross-sectional } \\
\text { study }\end{array}$ & 62 children with ASD & $\begin{array}{l}\text { Parent-reported diagnosis; } \\
\text { Non-Communicating } \\
\text { Children's Pain } \\
\text { Checklist-Revised. }\end{array}$ & CSHQ. & $\begin{array}{l}93 \% \text { of the sample scored above } 41 \text { on } \\
\text { the CSHQ. Pain predicted overall sleep } \\
\text { disturbance and three specific sleep } \\
\text { problems: sleep duration, parasomnias, and } \\
\text { sleep-disordered breathing. These specific } \\
\text { sleep problems were predicted by specific } \\
\text { modalities of nonverbal pain communication. }\end{array}$ & $\begin{array}{l}\text { Parental report of } \\
\text { diagnosis and all } \\
\text { data. }\end{array}$ \\
\hline $\begin{array}{l}\text { May et al. (109) } \\
\text { Australia }\end{array}$ & Case-control study & $\begin{array}{l}46 \text { children with ASD; } 38 \text { TD } \\
\text { children ( } 7-12 \text { years). }\end{array}$ & $\begin{array}{l}\text { DSM-IV-TR diagnostic } \\
\text { criteria; Social } \\
\text { Responsiveness Scale; } \\
\text { Wechsler Intelligence } \\
\text { Scale for Children-Fourth } \\
\text { Edition; Spence Children's } \\
\text { Anxiety Scale. }\end{array}$ & CSHQ. & $\begin{array}{l}\text { The ASD group had more sleep disturbance } \\
\text { than the TD group. Sleep disturbance } \\
\text { at baseline predicted later anxiety. Sleep } \\
\text { disturbance decreased over the year in } \\
\text { children with ASD, but not in TD children. } \\
\text { Reduced sleep disturbance was associated } \\
\text { with improved social ability. }\end{array}$ & $\begin{array}{l}\text { No evaluation of } \\
\text { sleep parameters by } \\
\text { objective measures; } \\
\text { only high- } \\
\text { functioning children } \\
\text { analyzed. }\end{array}$ \\
\hline $\begin{array}{l}\text { Mazurek \& } \\
\text { Petrosky (110) } \\
\text { USA }\end{array}$ & $\begin{array}{l}\text { Cross-sectional } \\
\text { study }\end{array}$ & $\begin{array}{l}1347 \text { children and adolescents } \\
\text { enrolled in the Autism Speaks } \\
\text { Autism Treatment Network. }\end{array}$ & $\begin{array}{l}\text { ADOS; CBCL; Short } \\
\text { Sensory Profile. }\end{array}$ & CSHQ. & $\begin{array}{l}\text { Anxiety was associated with all types of sleep } \\
\text { problems (bedtime resistance, sleep-onset } \\
\text { delay, short sleep duration, sleep anxiety, } \\
\text { and night waking). Sensory responsivity was } \\
\text { correlated with sleep problem, but it was } \\
\text { not significantly associated with bedtime } \\
\text { resistance or sleep anxiety for younger } \\
\text { children. }\end{array}$ & $\begin{array}{l}\text { No evaluation of } \\
\text { sleep parameters by } \\
\text { objective measures; } \\
\text { absence of a control } \\
\text { group. }\end{array}$ \\
\hline Wang et al. (111) & $\begin{array}{l}\text { Cross-sectional } \\
\text { study }\end{array}$ & $\begin{array}{l}60 \text { Chinese children with ASD } \\
\text { (6-17 years). }\end{array}$ & $\begin{array}{l}\text { DSM-IV-TR diagnostic } \\
\text { criteria. }\end{array}$ & $\begin{array}{l}\text { CSHQ; Strengths and } \\
\text { Difficulties Questionnaire. }\end{array}$ & $\begin{array}{l}\text { Sleep disturbances were severe and } \\
\text { common, with rates of } 70.0 \% \text { for overall } \\
\text { disturbances and } 15.0 \% \text { (daytime sleepiness) } \\
\text { to } 40.0 \% \text { (sleep duration) for specific } \\
\text { domains. Female gender, older parental age, } \\
\text { higher hyperactivity, and poorer prosocial } \\
\text { behavior were associated with increased } \\
\text { overall sleep disturbances. }\end{array}$ & $\begin{array}{l}\text { Absence of a } \\
\text { control group; no } \\
\text { evaluation of sleep } \\
\text { parameters by } \\
\text { objective measures. }\end{array}$ \\
\hline $\begin{array}{l}\text { Hirata et al. (112) } \\
\text { Japan }\end{array}$ & Case-control study & $\begin{array}{l}965 \text { community; } 193 \\
\text { preschoolers with ASD }\end{array}$ & $\begin{array}{l}\text { DSM-5 diagnostic criteria; } \\
\text { ADOS-G; CBCL. }\end{array}$ & $\begin{array}{l}\text { Japanese Sleep } \\
\text { Questionnaire for } \\
\text { Preschoolers. }\end{array}$ & $\begin{array}{l}\text { Preschoolers with ASD had more sleep } \\
\text { problems, including OSA, than those in } \\
\text { the community, sleep problems, especially } \\
\text { insomnia, correlated with behavioral problems } \\
\text { in preschoolers with ASD. }\end{array}$ & $\begin{array}{l}\text { No evaluation of } \\
\text { sleep parameters by } \\
\text { objective measures. }\end{array}$ \\
\hline $\begin{array}{l}\text { Hundley et al. (113) } \\
\text { New York }\end{array}$ & $\begin{array}{l}\text { Cross-sectional } \\
\text { study }\end{array}$ & $\begin{array}{l}532 \text { children with ASD (2-17 } \\
\text { years). }\end{array}$ & $\begin{array}{l}\text { DSM-IV-TR diagnostic } \\
\text { criteria; ADOS; ADI-R; } \\
\text { CBCL. }\end{array}$ & CSHQ. & $\begin{array}{l}\text { Repetitive sensor/motor behaviors were } \\
\text { positively associated with parent-reported } \\
\text { sleep problems, and the relationship remained } \\
\text { significant after controlling for anxiety } \\
\text { symptoms. Insistence on sameness was not } \\
\text { significantly associated with sleep problems. }\end{array}$ & $\begin{array}{l}\text { No evaluation of } \\
\text { sleep parameters by } \\
\text { objective measures; } \\
\text { absence of a control } \\
\text { group. }\end{array}$ \\
\hline
\end{tabular}




\begin{tabular}{|c|c|c|c|c|c|c|}
\hline $\begin{array}{l}\text { Authors } \\
\text { (Ref.) } \\
\text { country }\end{array}$ & Study design & Sample size & ASD assessment & $\begin{array}{l}\text { Sleep-wake cycle } \\
\text { assessment }\end{array}$ & Results & Major limitations \\
\hline $\begin{array}{l}\text { Irwanto et al. (114) } \\
\text { Indonesia and } \\
\text { Japan }\end{array}$ & $\begin{array}{l}\text { Cross-sectional } \\
\text { study }\end{array}$ & 50 children with ASD. & DSM-5 diagnostic criteria. & CSHQ. & $\begin{array}{l}\text { There were significant differences in total night } \\
\text { and early awakenings between Indonesian } \\
\text { and Japanese children. }\end{array}$ & $\begin{array}{l}\text { Small sample } \\
\text { size; absence of a } \\
\text { control group. No } \\
\text { evaluation of sleep } \\
\text { parameters by } \\
\text { objective measures. }\end{array}$ \\
\hline $\begin{array}{l}\text { Fletcher et al. (115) } \\
\text { England }\end{array}$ & Case-control study & $\begin{array}{l}21 \text { children with ASD; } 29 \text { TD } \\
\text { children. }\end{array}$ & $\begin{array}{l}\text { DSM-IV-TR diagnostic } \\
\text { criteria; Spence Children's } \\
\text { Anxiety Scale; Social } \\
\text { Worries Questionnaire; } \\
\text { Bedtime Routines } \\
\text { Questionnaire }\end{array}$ & $\begin{array}{l}\text { CSHQ; } 14 \text { nights of } \\
\text { actigraphy }\end{array}$ & $\begin{array}{l}\text { There was a significant reduction in sleep } \\
\text { duration over time in both groups, and } \\
\text { the ASD one showed more night-to-night } \\
\text { variability in sleep quality. Reductions in } \\
\text { actigraphy-derived sleep efficiency were } \\
\text { associated with an increased frequency of } \\
\text { maladaptive activities in the hour before } \\
\text { bedtime, in children with and without ASD. }\end{array}$ & Small sample size. \\
\hline $\begin{array}{l}\text { Mazurek et al. (116) } \\
\text { New York }\end{array}$ & $\begin{array}{l}\text { Cross-sectional } \\
\text { study }\end{array}$ & 81 children with ASD. & $\begin{array}{l}\text { Physical Aggression and } \\
\text { the Hostility subscales } \\
\text { of the Children's } \\
\text { Scale for Hostility and } \\
\text { Aggression: Reactive/ } \\
\text { Proactive (C-SHARP); } \\
\text { the Inattention and the } \\
\text { Hyperactivity subscales } \\
\text { of the Vanderbilt Attention } \\
\text { Deficit/Hyperactivity } \\
\text { Disorder Parent Rating } \\
\text { Scale (VADPRS). }\end{array}$ & CSHQ. & $\begin{array}{l}\text { Sleep problems were significantly associated } \\
\text { with physical aggression, irritability, } \\
\text { inattention, and hyperactivity. Night } \\
\text { awakenings had the most consistently strong } \\
\text { association with daytime behavior problems, } \\
\text { even after controlling for the effects of age } \\
\text { and sex. }\end{array}$ & $\begin{array}{l}\text { No evaluation of } \\
\text { sleep parameters } \\
\text { by standardized } \\
\text { measure. }\end{array}$ \\
\hline $\begin{array}{l}\text { Kheirouri et al. (117) } \\
\text { Turkey }\end{array}$ & Case-control study & $\begin{array}{l}35 \text { children with autism; } 31 \text { TD } \\
\text { subjects }\end{array}$ & $\begin{array}{l}\text { DSM-IV-TR diagnostic } \\
\text { criteria. }\end{array}$ & CSHQ. & $\begin{array}{l}\text { There was no significant association between } \\
\text { Gl problems and autism severity, but a } \\
\text { significant positive correlation have been } \\
\text { found between different indicators of sleep } \\
\text { disorders and severity of autism. Plasma } \\
\text { levels of serotonin were significantly high in } \\
\text { autistic children, but no significant association } \\
\text { with sleep problems. }\end{array}$ & $\begin{array}{l}\text { Small sample size; } \\
\text { no evaluation of } \\
\text { sleep parameters } \\
\text { by standardized } \\
\text { measure. }\end{array}$ \\
\hline $\begin{array}{l}\text { Mutluer et al. (118) } \\
\text { Turkey }\end{array}$ & Case-control study & $\begin{array}{l}64 \text { patients with ASD; } 53 \text { TD } \\
\text { subjects. }\end{array}$ & $\begin{array}{l}\text { DSM-IV-TR diagnostic } \\
\text { criteria; CARS; CBCL. }\end{array}$ & $\begin{array}{l}\text { Pediatric sleep } \\
\text { questionnaire. }\end{array}$ & $\begin{array}{l}\text { Children with ASD had higher frequency of } \\
\text { sleep problems, snoring, breathing problems, } \\
\text { behavioral problems compared with healthy } \\
\text { children; sleep latency was prolonged in } \\
\text { children with ASD compared with healthy } \\
\text { subjects. }\end{array}$ & $\begin{array}{l}\text { No evaluation of } \\
\text { sleep parameters } \\
\text { by standardized } \\
\text { measures; no } \\
\text { gender and other } \\
\text { confounding factors } \\
\text { examination. }\end{array}$ \\
\hline
\end{tabular}




\begin{tabular}{|c|c|c|c|c|c|c|}
\hline $\begin{array}{l}\text { Authors } \\
\text { (Ref.) } \\
\text { country }\end{array}$ & Study design & Sample size & ASD assessment & $\begin{array}{l}\text { Sleep-wake cycle } \\
\text { assessment }\end{array}$ & Results & Major limitations \\
\hline $\begin{array}{l}\text { Veatch et al. (119) } \\
\text { USA and Canada }\end{array}$ & Cross-sectional & $\begin{array}{l}80 \text { children with autism and } \\
\text { sleep onset delay ( } 2-10 \text { years). }\end{array}$ & $\begin{array}{l}\text { DSM-IV-TR diagnosis } \\
\text { criteria; ADOS. }\end{array}$ & CSHQ; actigraphy. & $\begin{array}{l}\text { Reported problems with sleep onset delay } \\
\text { were concurrent with sleep duration problems } \\
\text { in } 66 \% \text { of children, night wakings in } 72 \% \text { of } \\
\text { children, and bedtime resistance in } 66 \% \text { of } \\
\text { children; } 38 \% \text { of children reported insomnia. } \\
\text { Parent reports and actigraphy results were in } \\
\text { accordance. }\end{array}$ & $\begin{array}{l}\text { Relatively small } \\
\text { sample size. }\end{array}$ \\
\hline $\begin{array}{l}\text { Aathira et al. (120) } \\
\text { New Delhi } \\
\text { India }\end{array}$ & Longitudinal study & $\begin{array}{l}71 \text { children with ASD; } 65 \text { TD } \\
\text { children. }\end{array}$ & $\begin{array}{l}\text { DSM IV diagnostic } \\
\text { criteria; CARS; DP-3 } \\
\text { (Developmental Profile-3). }\end{array}$ & PSG (48 subjects); CBCL. & $\begin{array}{l}\text { The prevalence of poor sleepers among } \\
\text { ASD and controls were } 77.5 \% \text { and } 29.2 \% \text {, } \\
\text { respectively. The salient findings on PSG were } \\
\text { reduced sleep efficiency, decreased REM } \\
\text { and SWS duration } 1 \text {. The CBCL score was } \\
\text { significantly high in poor sleepers compared } \\
\text { to good sleepers on CSHQ. There was no } \\
\text { correlation of CARS or DP-3 score with sleep } \\
\text { problems in ASD children. }\end{array}$ & $\begin{array}{l}\text { Small sample size; } \\
\text { PSG only for a } \\
\text { night. }\end{array}$ \\
\hline $\begin{array}{l}\text { Kose et al. (121) } \\
\text { Turkey }\end{array}$ & $\begin{array}{l}\text { Retrospective } \\
\text { cross-sectional } \\
\text { study }\end{array}$ & $\begin{array}{l}48 \text { children with ASD; } 46 \\
\text { children with ID; } 48 \text { TD children } \\
\text { (2-18 years). }\end{array}$ & $\begin{array}{l}\text { DSM-5 diagnostic } \\
\text { criteria; CARS; Wechsler } \\
\text { Intelligence Scale } \\
\text { for Children-Revised } \\
\text { (WISC-R); Ankara } \\
\text { Developmental Screening } \\
\text { Inventory (ADSI). }\end{array}$ & CSHQ. & $\begin{array}{l}\text { Children with NDD had a } 2.8 \text {-fold increased } \\
\text { risk of sleep disturbance, 3.1-fold increased } \\
\text { risk for history of sleep disorders in parents, } \\
\text { 3.3-fold increased risk for psychiatric } \\
\text { comorbidity, } 13.1 \text {-fold increased risk for } \\
\text { co-sleeping with parents. Co-sleeping with } \\
\text { parents and family history of sleep problems } \\
\text { increased the risk of sleep disturbances. }\end{array}$ & $\begin{array}{l}\text { No evaluation of } \\
\text { sleep parameters } \\
\text { by standardized } \\
\text { measures; Turkish } \\
\text { adaptations of } \\
\text { ADI-R and ADOS } \\
\text { are not yet available. }\end{array}$ \\
\hline $\begin{array}{l}\text { Sannar et al. (122) } \\
\text { USA }\end{array}$ & $\begin{array}{l}\text { Cross-sectional } \\
\text { study }\end{array}$ & $\begin{array}{l}106 \text { hospitalized children } \\
\text { and adolescents with ASD } \\
\text { (9.5-16.3 years). }\end{array}$ & $\begin{array}{l}\text { Aberrant Behavior } \\
\text { Checklist-Community } \\
\text { (ABC-C); ADOS-2. }\end{array}$ & Sleep habits. & $\begin{array}{l}\text { High scores on the ABC-C (irritability, } \\
\text { stereotypy, and hyperactivity subscales) } \\
\text { at admission were significantly associated } \\
\text { with fewer minutes slept during the last } \\
\text { five nights of hospitalization. There was } \\
\text { no association between total awakenings } \\
\text { and ABC-C scores or ADOS-2 comparison } \\
\text { scores. }\end{array}$ & $\begin{array}{l}\text { No evaluation of } \\
\text { sleep parameters } \\
\text { by standardized } \\
\text { measures; absence } \\
\text { of a control group. }\end{array}$ \\
\hline
\end{tabular}


Authors

Study design

Sample size

ASD assessment

Sleep-wake cycle

Results

Major limitations

country

Veatch et al. (123)

Cross-sectional

2714 children in the Simons

$D S M-5$ diagnostic criteria; ADI-R; ADOS; Differential Ability Scales, 2nd Edition Mullen Scales of Early

Learning.

Parental report of sleep;

actigraphy; CBCL.

Sleep duration and severity of core ASD symptoms were negatively correlated, sleep duration and IQ scores were positively correlated. Severe social impairment was strongly associated with short sleep duration. Increased severity for numerous maladaptive behaviors, as well as reports of attention deficit disorder, depressive disorder, and obsessive compulsive disorder were associated with short sleep duration. Severity scores for social/communication impairment and restricted and repetitive behaviors were increased, IQ scores were decreased in children who reported to sleep 420 min per night compared to children sleeping $660 \mathrm{~min}$

\section{Verhoeff et al. (124) Longitudinal study 5151 children (81 children with DSM IV/5 diagnostic} Netherlands criteria; Pervasive

Developmental Problems score (PDP) of the CBCL Social Responsiveness Scale (SRS)
Sleep Problem Scale.

Sleep problems in early childhood were prospectively associated with a higher SRS score, but not when correcting for baseline PDP score. A higher SRS score and an ASD diagnosis were associated with more sleep problems at later ages, even when adjusting for baseline sleep problems. A trajectory of increasing sleep problems was associated with ASD.
No evaluation of sleep parameters by standardized measures; wide age range; use of medication.

No evaluation of sleep parameters by standardized measures; absence of a control group.

DSM, Diagnostic and Statistical Manual; ICD-10, International Classification of Diseases-10; $A S D$, autism spectrum disorder; $A S$, Asperger syndrome; HFA, high-functioning autism; PDD, pervasive developmental disorders; DD, developmental delay: CSHQ. Children's Sleep Habits Questionnaire; CARS, Childhood Autism Rating Scale; ASSQ. The High-Functioning Autism Spectrum Screening Questionnaire; ADI, Autism Diagnostic Interview; ADOS, Autism Diagnostic Observation Schedules; PSG, polysomnography; CBCL, child behavior checklist; IQ, intelligence quotient; TD, typically development; WHO, World Health Organization; REM, rapid eye movement. 
frequent nighttime awakenings $(58,63,65,70,72,78,85$, $91,104,107,119)$, early morning awakenings $(63,65,72)$, low sleep efficiency $(85,91)$, short time duration $(58,63,72,109$, 104, 119), and daytime sleeplessness (71, 109). Nightmares, morning headaches, crying during sleep, sleep apnea (72), and sleepwalking $(64,72)$ were also frequent. Although sleep problems were significant across all ages, subjects during adolescence tend to show a shorter sleep duration than toddlers who tend to present more frequent bedtime resistance, sleep anxiety, parasomnias, and night awakenings $(98,115)$. Some of the studies reviewed have analyzed sleep disturbances by means of the polysomnographic registrations in autistic subjects. Studies have shown a significant reduction of REM sleep proportion and a significant presence of REM activity in non-REM sleep compared to subjects with normal development $(66,69)$. One study $(66)$ on 10 autistic children and 8 children with Down Syndrome reported sleep continuity was disturbed by an increased number of night awakenings with a consequent reduction of sleep efficiency. In a later study (68), patients with AS showed a decrease in sleep time in the first two-thirds of the night and an increase in number of shifts into REM sleep from night awakenings. As reported in other studies, subjects with ASD may experience prolonged sleep latency, decreased sleep efficiency, and decreased sleep duration on the first night of polysomnographic registration $(80,93,120)$. Studies based on actigraphic registrations confirmed the data recorded using logs and/or sleep diaries observing frequent early night arousals, a delay of sleep period, insomnia, and less total sleep time within the $24 \mathrm{~h}$ in autistic children $(67,86,87$, $90,126)$. As reported in several studies, insomnia and sleepiness were correlated to the severity and prevalence of typical autism behavioral symptoms $(69,71,73,76,77,83,84,95,99,100,112$, 113). In particular, a study of Schreck et al. (73) found a correlation between insomnia and the prevalence of communication problems due to an increased sensitivity to stimuli in the sleeping environment. Further studies $(101,111)$ found a correlation between typical autistic behaviors and chronic insomnia. Children with ASD and poor sleep were characterized by a major representation of symptoms of autism such as restricted/ repetitive behaviors $(91,113)$, language impairment, problems with reciprocal social interactions, low overall intelligence $(80,100,103,109)$, and even physical aggression, irritability, and oppositional defiant disorder $(83,84,116,122)$. Affective disturbances, particularly depression (80) and anxiety-related problems $(71,95,103,105,109)$, have even been described in ASD with poor sleep. Some research groups $(97,100,106)$ have analyzed the relation between insomnia, psychopathology, and daytime functioning in both children and adolescents with autism and reported a severity of depressed mood, anxiety, and daytime functioning in relation to sleep disturbances. Rzepecka and colleagues (95) reported a significant correlation between sleep problems, challenging behavior, and anxiety in children with intellectual disability and/or ASD. This study indicated that the $41.9 \%$ of the variance of challenging behavior was predicted by sleep problems and anxiety. The first study (110) that has analyzed the relationship between anxiety, sensory problems, and sleep disturbances in autism showed that children with anxiety and sensory overresponsivity may be particularly predisposed to develop sleep problems. A recent study of Veatch et al. (123) has demonstrated that shorter sleep duration was associated not only with depressive and obsessive-compulsive disorders but also with social impairment such as a failure to develop peer relationships and with maladaptive behaviors in ASD. Children who reported $7 \mathrm{~h}$ of sleep per night showed a severe impairment in social/ communication compared to ASD children who tended to sleep 10-11 h per night (123). Anxiety, autism symptom severity, sensory sensitivities, snoring, obstructive sleep apneas, pain, and gastrointestinal problems were also associated with sleep disturbances $(103,108,112,118)$. In summary, sleep disturbances are frequent in children and adolescents with ASD. Insomnia and sleepiness were the most commonly reported symptoms together with long sleep latency, long time spent awake after sleep onset, early time awakening, and short sleep time. As shown in several studies, sleep disturbances have been related to the severity of ASD symptoms such as difficulties in social interaction and communication, presence of stereotypic behaviors, as well as anxiety and depressive symptoms.

\section{Circadian Sleep Dysrhythmicity in Adults With Autism Spectrum Disorder}

Five studies analyzed the circadian rhythmicity in adults with ASD (Table 3). The most frequent circadian sleep disorders was the delayed sleep phase $(126,128-130)$. The most recent study (130) has investigated two groups (41 adults with ASD and intellectual disability versus 51 normal development) by means of ambulatory circadian monitoring, recording temperature, motor activity, body position, sleep, and light intensity; the circadian phase advanced was more common in the ASD group compared to controls. In summary, despite the fact that a few studies have investigated circadian sleep dysrhythmicity in adults with ASD, all the results showed that a delayed sleep phase is frequent in adults with ASD.

\section{Sleep Disturbances in Adults With Autism Spectrum Disorder}

To date, only nine studies have described the sleep pattern on adults with ASD (Table 4). Three studies conducted from the same group (131-133) that compared AS to controls have shown similar polysomnographic sleep patterns. On the other hand, some further studies have suggested that $80 \%$ of adolescents and young adults with autism and AS may experience sleep problems $(68,106,135)$. Sleep disturbances described in adults with ASD were similar to those described in children and were characterized by low sleep efficiency, short sleep duration, long sleep latency, frequent nighttime awakenings, and daytime sleepiness $(135,137)$. High-functioning adults with ASD reported insomnia and/or a significant phase advancement showing longer sleep latency, more frequent nocturnal awakenings, lower sleep efficiency, increased duration of NREM stage 1, and decreased non-REM slow-wave sleep compared to the healthy control group (134). Further, low total sleep time was correlated with social and communication impairments in autistic subjects $(106,134)$. Some authors have also reported that the presence of poor sleep in adults with high-functioning autism correlated with various aspects of 
Authors

Study

Sample size

ASD assessment

Sleep-wake cycle assessment

Results

Major limitations

country

Hare et al. (126) Comparative 10 adults with AS;

Manchester, UK study

18 TD adults.

ICD-10 or DSM-IV

diagnostic criteria;

ASQ.

Hare et al. (127)

Manchester, UK

Comparative

31 adults with ID, of

whom 14 had an ASD.

IQ score; DSM IIIR/

IV diagnostic criteria;

ASSQ; British Picture

Vocabulary Scale

(BPVS)

Baker and Cross-sectional 36 adults with ASD;

Richdale (128) study 36 TD adults.

Australia

AQ; ADOS-2.

$\begin{array}{ll}\text { Goldman et al. } & \text { Comparative } \\ \text { (129) } & \text { study }\end{array}$

28 adolescents/young adults with ASD; 13 age/sex matched TD individuals (11-26 years). diagnostic criteria; ADOS.

$\begin{array}{llll}\text { Ballester et al. } & \text { Case-control } & 41 \text { adults with ASD and } & \text { DSM-5 diagnostic } \\ \text { (130) } & \text { study } & \text { ID }(<70) ; 51 \text { TD adults. } & \text { criteria. } \\ \text { Spain } & & \end{array}$

(130)

ID (<70); 51 TD adults.

criteria.

14-day sleep-wake diary,

14-day actigraphy assessment:

Composite Scale of Morningness

questionnaire.

Actigraphy; basic sleep diary

Actigraphy; basic sleep diary

Adolescent Sleep-Wake Scale; Adolescent Sleep-Hygiene Scale; 4 weeks actigraphy; melatonin salivary collections (over 4 nights, starting at $6: 00 \mathrm{pm}$ and repeated every 30 min until bedtime): salivary cortisol collected immediately before bedtime and immediately upon awakening for 4 days starting on the morning after the last night of melatonin sample collection.

Ambulatory circadian monitoring (ACM) device has three different sensors: Wrist temperature actimeter information (motor activity and body position), light intensity; 7-day sleep-wake diary.
Adults with AS showed significant phase advancement in the sleep-wake cycle with longer sleep latency, lower sleep efficiency, and more fragmented sleep than TD ones.

No significant differences in sleep quantity and quality between the participants depending on whether they had an ASD.

Delayed sleep-wake phase disorder, advanced sleep-wake phase disorder, and non-24-h sleep-wake rhythm disorder were present in the participants. A higher proportion of adults with ASD met criteria for a circadian rhythm sleep-wake disorder (CRSWD) compared to control adults delayed sleep-wake phase disorder.

Compared to those with TD, adolescents/ young adults with ASD had longer sleep latencies and more difficulty going to bed and falling asleep. Morning cortisol, evening cortisol, and the morning-evening difference in cortisol did not differ by diagnosis (ASD vs. TD). Dim light melatonin onsets (DLMOs) averaged across participants were not different for the ASD and TD participants.

Circadian phase advance in the ASD group was suggested by the higher values for wrist temperature and sleep and the lower moto activity and body position during the late afternoon and the first part of the night when compared to controls.

Individuals with ASD and ID presented sleep difficulties (low sleep efficiency, prolonged sleep latency and increased number and length of night awakenings), together with daily sedentary behavior, increased nocturnal activity and a consistent phase advance in circadian rhythms.
Small sample size; participants recruited from a relatively small area; need for more closely matched participants.

Small sample; participants recruited from a relatively small area; use of medication; people with unidentified ASD symptoms in the non-autistic group.

Small sample size; no evaluation of factors that contribute to CRSWDs.

Small sample size; emphasized HFA; participants with erratic sleep schedules, a broad age range and taking medications; not define circadian preference psychiatric comorbidities.

Small sample size; ACM has not been validated in ASD to study sleep; most ASD were medicated; the group with ASD was not matched with the contro group on sex, IQ, employment status, or living conditions.

DSM, Diagnostic and Statistical Manual; TD, typically development; ID, intellectual disabilities; IQ, intelligence quotient; ICD-10, International Classification of Diseases-10; ASD, autism spectrum disorder; AS, Asperger syndrome; HFA, high-functioning autism; ADOS, Autism Diagnostic Observation Schedules; ASQ, Autism Screening Questionnaire; AQ, autism quotient. 
TABLE 4 | Clinical studies on sleep disturbances in autism spectrum disorder in adults.

\begin{tabular}{|c|c|c|c|c|c|c|}
\hline $\begin{array}{l}\text { Authors } \\
\text { (Ref.) } \\
\text { country }\end{array}$ & Study design & Sample size & ASD assessment & $\begin{array}{l}\text { Sleep-wake cycle } \\
\text { assessment }\end{array}$ & Results & Major limitations \\
\hline $\begin{array}{l}\text { Godbout et al. (68) } \\
\text { Canada }\end{array}$ & Case-control study & $\begin{array}{l}8 \text { patients with AS (7-53 } \\
\text { years); } 8 \text { age-/gender- } \\
\text { matched TD subjects. }\end{array}$ & $\begin{array}{l}\text { DSM-IV diagnostic } \\
\text { criteria; ADI. }\end{array}$ & $\begin{array}{l}\text { Sleep was recorded for } \\
\text { two consecutive nights and } \\
\text { scored according to standard } \\
\text { methods using } 20 \text {-s epochs }\end{array}$ & $\begin{array}{l}\text { Patients with AS showed decreased sleep time in } \\
\text { the first two-thirds of the night, increased number } \\
\text { of shifts into REM sleep from a waking epoch, and } \\
\text { all but one patient showed signs of REM sleep } \\
\text { disruption. EEG sleep spindles were significantly } \\
\text { decreased while K complexes and REM sleep } \\
\text { rapid eye movements were normal. Three patients } \\
\text { with AS, but none of the comparison participants, } \\
\text { showed a pathological index of periodic leg } \\
\text { movements in sleep. }\end{array}$ & $\begin{array}{l}\text { Small sample size; } \\
\text { use of medications }\end{array}$ \\
\hline $\begin{array}{l}\text { Tani et al. (131) } \\
\text { Helsinki, Finland }\end{array}$ & Case-control study & $\begin{array}{l}20 \text { AS patients; } 10 \text { TD } \\
\text { subjects. }\end{array}$ & $\begin{array}{l}\text { DSM III-R diagnostic } \\
\text { criteria; Beck Depression } \\
\text { Inventory; Wechsler adult } \\
\text { intelligence scale, revised } \\
\text { version; ASSQ. }\end{array}$ & $\begin{array}{l}\text { Basic Nordic Sleep } \\
\text { Questionnaire; 6-day sleep } \\
\text { diary. }\end{array}$ & $\begin{array}{l}\text { AS adults reported frequent insomnia in all } \\
\text { measures. }\end{array}$ & Small sample size. \\
\hline $\begin{array}{l}\text { Tani et al. (132) } \\
\text { Helsinki, Finland }\end{array}$ & Case-control study & $\begin{array}{l}20 \text { adults with insomnia } \\
\text { (19.9-34.5 years); } 10 \\
\text { age-/gender-/education- } \\
\text { matched TD subjects. }\end{array}$ & $\begin{array}{l}\text { DSM-IV-TR diagnostic } \\
\text { criteria. }\end{array}$ & $\begin{array}{l}\text { 2-nights PSG. Results of the } \\
\text { second night recordings were } \\
\text { included in the analysis. }\end{array}$ & $\begin{array}{l}\text { AS subjects displayed a similar PSG profile } \\
\text { compared with controls. Sleep periods were equal } \\
\text { in both groups with a great amount of slow-wave } \\
\text { sleep in the early part of the night. The only sign } \\
\text { indicating decreased sleep continuity in autistic } \\
\text { subjects was the greater proportion of wake after } \\
\text { sleep onset. }\end{array}$ & Small sample size. \\
\hline $\begin{array}{l}\text { Tani et al. (133) } \\
\text { Finland }\end{array}$ & Longitudinal study & $\begin{array}{l}20 \text { adults with AS; } 10 \\
\text { age-/sex-/intelligence- } \\
\text { matched TD adults. }\end{array}$ & Clinical diagnosis. & Actigraphy. & $\begin{array}{l}\text { People with AS did not differ from the controls } \\
\text { regarding actigraphic sleep profiles. }\end{array}$ & Small sample size. \\
\hline $\begin{array}{l}\text { Limoges et al. (134) } \\
\text { Canada }\end{array}$ & Cross-sectional study & $\begin{array}{l}27 \text { adults with HFA } \\
\text { (16-27 years); } 78 \text { TD } \\
\text { subjects (16-30 years). }\end{array}$ & $\begin{array}{l}\text { DSM-IV diagnostic } \\
\text { criteria; ADI-R; Wechsler } \\
\text { Adult Intelligence Scale } \\
\text { 3ed. }\end{array}$ & $\begin{array}{l}\text { Sleep habits questionnaire; } \\
\text { Horne and Os̈tberg's } \\
\text { questionnaire to determine } \\
\text { morningness-eveningness } \\
\text { typology; laboratory sleep } \\
\text { recordings for two consecutive } \\
\text { nights; Achenbach Youth } \\
\text { Self-Report scale to measure } \\
\text { of adaptive behaviors; State- } \\
\text { Trait Anxiety Inventory; Beck } \\
\text { Depression Inventory; Cortisol } \\
\text { saliva samples. }\end{array}$ & $\begin{array}{l}\text { Autism group: a longer sleep latency, more } \\
\text { frequent nocturnal awakenings, lower sleep } \\
\text { efficiency, increased duration of stage } 1 \text { sleep, } \\
\text { decreased non-REM sleep and slow-wave } \\
\text { sleep, fewer stage } 2 \text { EEG sleep spindles, and a } \\
\text { lower number of rapid eye movements during } \\
\text { REM sleep vs. TD participants; no differences } \\
\text { between group on the Beck Depression Inventory; } \\
\text { trait anxiety scores on the Spielberger Anxiety } \\
\text { Scale were higher in ASDs. Objective total sleep } \\
\text { time correlated negatively with the Social and } \\
\text { Communication scales of the ADI-R. The sleep } \\
\text { structure of clinical subgroups did not differ, } \\
\text { except fewer EEG sleep spindles in the Asperger } \\
\text { syndrome subgroup. }\end{array}$ & Small sample size. \\
\hline
\end{tabular}




\begin{tabular}{|c|c|c|c|c|c|c|}
\hline $\begin{array}{l}\text { Authors } \\
\text { (Ref.) } \\
\text { country }\end{array}$ & Study design & Sample size & ASD assessment & $\begin{array}{l}\text { Sleep-wake cycle } \\
\text { assessment }\end{array}$ & Results & Major limitations \\
\hline $\begin{array}{l}\text { Oyane and } \\
\text { Bjorvatn (135) } \\
\text { Bergen, Norway }\end{array}$ & Cross-sectional study & $\begin{array}{l}9 \text { adolescents and } \\
\text { young adults with } \\
\text { autistic disorder; } 6 \\
\text { adolescents and young } \\
\text { adults with AS; (15-25 } \\
\text { years) }\end{array}$ & Clinical diagnosis. & $\begin{array}{l}\text { Sleep questionnaire; Epworth } \\
\text { Sleepiness Scale; } 2 \text { weeks } \\
\text { sleep diaries; } 2 \text { weeks } \\
\text { actigraphy. }\end{array}$ & $\begin{array}{l}\text { Although the sleep questionnaires completed by } \\
\text { parents revealed only a moderate degree of sleep } \\
\text { problems, great sleep disturbances were recorded } \\
\text { with actigraphy. Low sleep efficiency (below } 85 \% \text { ) } \\
\text { or long sleep latency (more than } 30 \text { min) have } \\
\text { been found in } 80 \% \text { of the subjects. There was no } \\
\text { early morning awakening. }\end{array}$ & $\begin{array}{l}\text { Small sample } \\
\text { size; absence of a } \\
\text { control group. }\end{array}$ \\
\hline $\begin{array}{l}\text { Limoges et al. (136) } \\
\text { Canada }\end{array}$ & Case-control study & $\begin{array}{l}17 \text { adults with ASD (9 } \\
\text { with HFA and } 8 \text { with } \\
\text { AS); } 14 \text { TD individuals. }\end{array}$ & $\begin{array}{l}D S M-I V \text { diagnostic } \\
\text { criteria. ADI-R; a battery } \\
\text { of nonverbal tasks was } \\
\text { administered, in the } \\
\text { morning after a second } \\
\text { night of sleep in the } \\
\text { laboratory. }\end{array}$ & PSG. & $\begin{array}{l}\text { Signs of poor sleep in the autism group were } \\
\text { significantly correlated with either normal } \\
\text { performance (selective attention and declarative } \\
\text { memory) or inferior performance than controls } \\
\text { (sensory-motor and cognitive procedural } \\
\text { memories). Both groups presented a significant } \\
\text { negative correlation between slow-wave sleep and } \\
\text { learning a sensory-motor procedural memory task. }\end{array}$ & $\begin{array}{l}\text { Small sample size; } \\
\text { large number of } \\
\text { correlation. }\end{array}$ \\
\hline $\begin{array}{l}\text { Richdale et al. } \\
\text { (106) } \\
\text { Australia }\end{array}$ & Case-control study & $\begin{array}{l}27 \text { adolescents with } \\
\text { HFASD (14.2-16.8 } \\
\text { years); } 27 \text { age- } \\
\text { sex-matched TD; } \\
\text { adolescents (14.4-16.6 } \\
\text { years). }\end{array}$ & $\begin{array}{l}\text { The Centre for } \\
\text { Epidemiological Studies } \\
\text { Depression scale (CES- } \\
\text { D); the anxiety subscale } \\
\text { of the Depression, } \\
\text { Anxiety and Stress Scale } \\
\text { (DASS-21) }\end{array}$ & $\begin{array}{l}\text { 7-day sleep/wake diary; } \\
\text { actigraphy; Sleep Habits } \\
\text { Survey; Chronic Sleep } \\
\text { Reduction Questionnaire to } \\
\text { measure daytime functioning; } \\
\text { Sleep Anticipatory Anxiety } \\
\text { Questionnaire to measure } \\
\text { pre-sleep arousal. }\end{array}$ & $\begin{array}{l}\text { HFASD group reported significantly higher scores } \\
\text { for depressed mood, anxiety and pre-sleep } \\
\text { arousal vs. TD adolescents, and poorer daytime } \\
\text { functioning. More significant correlations between } \\
\text { sleep variables and psychopathology variables, } \\
\text { and sleep variables and daytime functioning in the } \\
\text { HFASD group, vs. TD group. }\end{array}$ & Small sample size. \\
\hline $\begin{array}{l}\text { Baker and Richdale } \\
\text { (137) } \\
\text { Australia }\end{array}$ & Cross-sectional study & $\begin{array}{l}36 \text { adults with HFASD; } \\
36 \text { age-/sex-/intelligence } \\
\text { quotient-matched TD } \\
\text { adults. }\end{array}$ & $\begin{array}{l}\text { Autism Quotient; } \\
\text { ADOS-2. }\end{array}$ & $\begin{array}{l}\text { Online questionnaire battery: } \\
\text { PSQI; } 14 \text { days sleep diary; } \\
14 \text { days actigraphy. }\end{array}$ & $\begin{array}{l}\text { HFASD group reported significantly more general } \\
\text { sleep disturbances, high scores on the PSQI, } \\
\text { long sleep onset latencies (actigraphy), and poor } \\
\text { sleep efficiency (diary) and these results remained } \\
\text { significant after accounting for the false discovery } \\
\text { rate. HFASD group reported significantly shorter } \\
\text { total sleep time, poorer refreshment scores upon } \\
\text { waking in the morning and higher scores on the } \\
\text { daytime dysfunction due to sleepiness subscale of } \\
\text { the PSQI compared to the TD group. }\end{array}$ & $\begin{array}{l}\text { Small sample size; } \\
\text { use of medications. }\end{array}$ \\
\hline
\end{tabular}

DSM, Diagnostic and Statistical Manual; ASD, autism spectrum disorder; AS, Asperger syndrome; HFA, high-functioning autism; ADI, Autism Diagnostic Interview; ADOS, Autism Diagnostic Observation Schedules; PSG, polysomnography; TD, typically development; REM, rapid eye movement; PSQI, Pittsburgh Sleep Quality Index. 
motor output on nonverbal performance tasks, suggesting that sleep disturbances in ASD might affect attention and/or memory components in the nonverbal modality (136). In summary, the main sleep problems in adults with ASD were insomnia, low sleep efficiency, short sleep duration, long sleep latency, frequent nighttime awakenings, and daytime sleepiness. As shown in some studies, sleep disturbances were related to difficulties in social interaction, communication, and cognitive performance.

\section{Melatonin and Autism Spectrum Disorder}

According to our research methods, we found 17 studies on the role of melatonin in circadian rhythm dysregulation in ASD (Table 5). Two different studies $(138,139)$ measured melatonin serum levels every $4 \mathrm{~h}$ for $24 \mathrm{~h}$ in autistic subjects compared to healthy controls. They found an abnormal melatonin circadian rhythm, low blood concentration during the night related to sleep disturbances, and a tendency to have high daytime melatonin levels in autistic subjects. A later study by Tordjman and colleagues (140) analyzes the overnight urinary excretion of the predominant melatonin metabolite, 6-sulfatoxymelatonin (6-SM). Sixty-three percent of post-pubertal subjects with ASD showed low 6-SM, most marked in males and prepubertal children; this finding was confirmed in a later study (145). Another research group (146) confirmed a reduction in urinary secretion of 6-SM in subjects with ASD. The previous results were confirmed in another study, and low nocturnal excretion of 6-SM was associated with a greater severity of autistic symptoms (verbal language and repetitive behaviors). In a study of Pagan et al., (150), patients with ASD showed higher serotonin and lower melatonin levels than healthy controls. Patients with melatonin deficit reported more frequent sleep-onset and sleep-maintenance insomnia than patients with normal melatonin levels. The same research group investigated, for the first time, melatonin synthesis in the pineal gland and in the gut of patients with ASD, reinforcing the hypothesis that the nocturnal increase in circulating melatonin was reduced in those subjects and caused by enzymatic disruption of both aralkylamine $\mathrm{N}$-acetyltransferase (AANAT) and acetylserotonin $O$-methyltransferase (ASMT) involved in melatonin synthesis confirming a melatonin reduction (153). An Afghanistan study (152) confirmed a reduction of melatonin serum level that was related to the severity of ASD symptoms. Recently, melatonin salivary concentrations have been studied in ASD subjects with and without anxiety and/or depression compared to controls (154). The timing of the dim light melatonin onset (DLMO) did not differ between the two groups, but advances and delays of the melatonin rhythms were the circadian sleep disorder more frequently observed in ASD subjects. Regarding the genetic pathways of melatonin, several studies focused on the variations of genes that regulate the synthesis, metabolism, and mechanism of action of melatonin. A multicenter study, the Paris Autism Research International (Sib-pair study) (141), sequenced all ASMT exons and promoters in 250 individuals with ASD. The ASD group showed non-conservative variations of the protein sequence of ASMT, and only two ASD families presented a splicing mutation. Forty-three individuals with ASD revealed a highly significant decrease of ASMT activity and melatonin level compared to 48 controls. Another subsequent research from the Sib-pair study (142) analyzed 941 individuals: 295 patients with ASD, 362 controls, and 284 individuals from different ethnic backgrounds. They sequenced MTNR1A and MTNR1B (melatonin receptor $1 \mathrm{~A}$ and $1 \mathrm{~B}$ ) genes coding for melatonin 1 (MT1) and melatonin 2 (MT2) receptors, and G protein-coupled receptor 50 (GPR50) gene, coding for the orphan melatoninrelated receptor GPR50. Authors found MTNR1A and MTNR1B non-synonymous mutations altering the functional properties of the human melatonin receptors. Regarding GPR50, they detected a significant association between ASD and two variations in affected males. In the same year, Sweden researchers (143) screened the genetic mutations of AANAT, ASMT, MTNR1A, MTNR1B, and GPR50, encoding both synthesis enzymes and the three main receptors of melatonin, in 109 patients with ASD and 188 controls. In this study, several rare variants were found in melatonin-related genes in patients with ASD, including the mutation in ASMT. A Chinese study (147) investigated all ASMT exons and the neighboring region in 398 individuals with ASD and 437 healthy controls. They detected new rare coding mutations of ASMT affecting the protein sequence only in six individuals of the ASD group, but the authors did not find significant differences of genotypic distribution and allele frequencies of the common SNPs in ASMT between groups. Only one study (148) investigated a large sample of 1,747 subjects by means of the analysis of the SNPs and the duplication of exons 2-8 in ASMT, in order to identify genes involved in autism psychopathology. The authors identified the association between one SNP in the last intron of ASMT and social interaction impairments in females, but they did not detect any relation with language impairment or restricted and repetitive behaviors. According to previous research, Veatch et al. (151) studied 15 ASD children with sleep disturbances, of whom 11 were treated with melatonin, and found that an association between sleep onset delay and dysfunctional variation in genes related to the melatonin pathway, especially with regard to cytochrome (CYP) 1A2. They also, observed a strong correlation between genotypes in ASMT and in CYP1A2, particularly in the subset of children who responded to treatment with supplemental melatonin. In summary, most of the studies that focused on autistic children have found abnormal melatonin circadian secretion and low blood and salivary melatonin concentrations during the night with a tendency to have high daytime melatonin levels. Regarding the genetic pathways of melatonin, several studies focused on the variations of genes that regulate the synthesis, metabolism, and mechanism of action of melatonin (AANAT, ASMT, MTNR1A, MTNR1B, and GPR50) showing several rare genetic variants of them. These findings have been related to sleep disturbances in ASD.

\section{DISCUSSION}

This systematic review aimed to provide the current status of knowledge about sleep disturbances and circadian sleep disorders in ASD across the lifespan. The current data have shown a number of several striking findings with regard to 
TABLE 5 | Clinical studies on melatonin in autism spectrum disorde.

\begin{tabular}{|c|c|c|c|c|c|c|c|}
\hline $\begin{array}{l}\text { Authors } \\
\text { (Ref.) } \\
\text { country }\end{array}$ & Study design & Sample size & ASD assessment & $\begin{array}{l}\text { Sleep-wake cycle } \\
\text { assessment }\end{array}$ & Melatonin (MT) & Results & Major limitations \\
\hline $\begin{array}{l}\text { Nir et al. (138) } \\
\text { Jerusalem, Israel }\end{array}$ & Case-control study & $\begin{array}{l}10 \text { males with ASD (16-30 } \\
\text { years); } 5 \text { TD subjects. }\end{array}$ & DSM-III diagnostic criteria. & & $\begin{array}{l}\text { Blood melatonin level } \\
\text { every } 4 \mathrm{~h} \text { for } 24 \mathrm{~h} \text {. }\end{array}$ & $\begin{array}{l}\text { Abnormal melatonin circadian } \\
\text { rhythm in autistic; amplitude of } \\
\text { melatonin peak lower in children } \\
\text { with autism than in controls; serum } \\
\text { melatonin higher during day and } \\
\text { lower during night than in controls. }\end{array}$ & $\begin{array}{l}\text { Small size sample. } \\
\text { No evaluation of } \\
\text { sleep parameters. }\end{array}$ \\
\hline $\begin{array}{l}\text { Kulman et al. } \\
\text { (139) } \\
\text { Italy }\end{array}$ & Case-control study & $\begin{array}{l}14 \text { children with autism; } 20 \\
\text { age-matched TD children. }\end{array}$ & DSM-III diagnostic criteria. & & $\begin{array}{l}\text { Blood melatonin level } \\
\text { every } 4 \mathrm{~h} \text { for } 24 \mathrm{~h} \text {. }\end{array}$ & $\begin{array}{l}\text { Significantly low melatonin level } \\
\text { in autistic; abnormal melatonin } \\
\text { circadian rhythm in all } 14 \\
\text { autistic children compared with } \\
\text { controls: children with ASD did } \\
\text { not demonstrate physiological } \\
\text { increase in melatonin during the } \\
\text { night. }\end{array}$ & $\begin{array}{l}\text { Small size sample; } \\
\text { no objective sleep } \\
\text { measures. No } \\
\text { evaluation of sleep } \\
\text { parameters. }\end{array}$ \\
\hline $\begin{array}{l}\text { Tordjman et al. } \\
(140)\end{array}$ & Case-control study & $\begin{array}{l}49 \text { children and } \\
\text { adolescents with autistic } \\
\text { disorder; } 88 \text { TD children } \\
\text { matched on age, sex, and } \\
\text { Tanner stage of puberty } \\
\text { (6-15 years). }\end{array}$ & $\begin{array}{l}\text { DSM-IV, ICD-10, and } \\
\text { CFTME diagnostic criteria; } \\
\text { ADI-R; ADOS-G; Wechsler } \\
\text { intelligence scales; } \\
\text { Kaufman-Assessment } \\
\text { Battery for Children } \\
\text { (K-ABC) }\end{array}$ & & $\begin{array}{l}\text { Urinary } 6-S M 12 \mathrm{~h} \\
\text { collection from } 8 \mathrm{pm} \\
\text { to } 8 \mathrm{am} .\end{array}$ & $\begin{array}{l}\text { Mean 6-SM lower than in controls; } \\
63 \% \text { of children with ASD had } \\
\text { low 6-SM, low 6-SM level was } \\
\text { significantly more common in males } \\
\text { and prepubertal children. }\end{array}$ & $\begin{array}{l}\text { No diurnal } \\
\text { melatonin } \\
\text { evaluation. No } \\
\text { evaluation of sleep } \\
\text { parameters. }\end{array}$ \\
\hline $\begin{array}{l}\text { Melke J et al. } \\
(141) \\
\text { Paris Autism } \\
\text { Research } \\
\text { International } \\
\text { Sipair study }\end{array}$ & $\begin{array}{l}\text { Case-control } \\
\text { study; multicentric } \\
\text { study }\end{array}$ & $\begin{array}{l}250 \text { autistic patients and } \\
\text { their parents; } 255 \text { TD } \\
\text { subjects. }\end{array}$ & $\begin{array}{l}\text { DSM-IV diagnostic } \\
\text { criteria; ADI-R; Social and } \\
\text { Communication Disorders } \\
\text { (DISCO-10); AS Diagnostic } \\
\text { Interview. }\end{array}$ & & $\begin{array}{l}\text { Sequencing ASMT } \\
\text { exons and promoters; } \\
\text { biochemical analyses } \\
\text { performed on blood } \\
\text { platelets and/or } \\
\text { cultured cells. }\end{array}$ & $\begin{array}{l}\text { Non-conservative variations } \\
\text { of ASMT including a splicing } \\
\text { mutation present in two families } \\
\text { with ASD, but not in controls. } \\
\text { Two polymorphisms located in } \\
\text { the promoter (rs4446909 and } \\
\text { rs5989681) were more frequent } \\
\text { in ASD compared to control and } \\
\text { were associated with a decrease } \\
\text { in ASMT transcripts in blood cell } \\
\text { lines. Highly significant decrease in } \\
\text { ASMT activity and melatonin level in } \\
\text { individuals with ASD. }\end{array}$ & $\begin{array}{l}\text { No evaluation of } \\
\text { sleep parameters. }\end{array}$ \\
\hline
\end{tabular}




\begin{tabular}{|c|c|c|c|c|c|}
\hline $\begin{array}{l}\text { Authors } \\
\text { (Ref.) } \\
\text { country }\end{array}$ & Study design & Sample size & ASD assessment & $\begin{array}{l}\text { Sleep-wake cycle } \\
\text { assessment }\end{array}$ & Melatonin (MT) \\
\hline $\begin{array}{l}\text { Chaste P et al. } \\
\text { (142) } \\
\text { Paris Autism } \\
\text { Research } \\
\text { International Sib- } \\
\text { pair study }\end{array}$ & $\begin{array}{l}\text { Case-control } \\
\text { study; multicentric } \\
\text { study }\end{array}$ & $\begin{array}{l}295 \text { patients with ASD } \\
\text { (AD = 222; AS = } 61 ; \\
\text { PDD-NOS = 12); } 362 \text { TD } \\
\text { subjects; } 284 \text { individuals } \\
\text { from different ethnic } \\
\text { backgrounds. }\end{array}$ & $\begin{array}{l}\text { DSM-IV diagnostic criteria; } \\
\text { ADI-R; AS Diagnostic } \\
\text { Interview. }\end{array}$ & $\begin{array}{l}\text { Actigraphy; analysis } \\
\text { of MT1-I49N } \\
\text { mutation. }\end{array}$ & $\begin{array}{l}\text { Sequenced MTNR1A, } \\
\text { MTNR1B, and } \\
\text { GPR50 genes } \\
\text { (coding for the } \\
\text { orphan melatonin- } \\
\text { related receptor } \\
\text { GPR50) in patients } \\
\text { and controls. }\end{array}$ \\
\hline
\end{tabular}

DSM-IV diagnostic criteria ADI-R.

DSM-IV-TR diagnostic criteria: ADI-R; ADOS. age-matched autistic individuals.

(144)

Netherlands

Case-control study Nashville, USA

Cross-sectiona study Picture Vocabulary Test-III
23 children with ASD (4-10
years)

ADOS; ADI-R; Peabody (PPVT-III); the Parental

Concerns Questionnaire (PCQ).

\section{Results}

6 non-synonymous mutations for MTNR1A and 10 for MTNR1B. Most of these variations altered receptor function. Mutants are MT1-I49N, which is devoid of any melatonin binding and cell surface expression, and MT1-G166E and MT1-1212T, which showed severely impaired cell surface expression. The prevalence of these deleterious mutations in cases and controls indicates that they do not represent a major risk factor for ASD (MTNR1A case $3.6 \%$ vs. controls $4.4 \%$; MTNR1B case $4.7 \%$ vs. $3 \%$ controls). They detected a significant association between ASD and two variations OF GPR50, D502-505 and T532A in affected males.
They have

investigated all the genes involved in the melatonin pathway by mutation screening of AA-NAT, ASMT, MTNR1A, MTNR1B, and GPR50.

Urinary excretion of 5-hydroxyindoleacetic acid (5-HIAA) and serotonin (5-HT).

vernight Urinary 6-SM.
Several rare variants were identified

in patients with ASD, including

splice site mutation in ASMT

(IVS5+2T > C). However, mutations

were found in upstream regulatory regions in three of the genes

investigated, ASMT, MTNR1A, and MTNR1B.

In the hyperserotonemic group,

significant increases at trend level in urinary excretion of 5-HIAA and 5-HT and a significant decrease

for 6-SM were found. The urinary 5-HIAA:5-HT ratio was similar in the normoserotonemic versus the hyperserotonemic groups.

No evaluation of sleep parameters.

Urinary 6-SM excretion rates are low in autistic subjects. Higher urinary 6-SM excretion rates were associated with increased N3 phase of sleep, decreased N2 phase of sleep, and daytime sleepiness. characterization

of daytime

and nighttime

melatonin

production in

autism. No

evaluation of sleep parameters.

Small sample size lack of a control group; did not obtain information on the specific segments of sleep; no repeated blood specimens of melatonin. 


\begin{tabular}{|c|c|c|c|c|c|c|c|}
\hline $\begin{array}{l}\text { Authors } \\
\text { (Ref.) } \\
\text { country }\end{array}$ & Study design & Sample size & ASD assessment & $\begin{array}{l}\text { Sleep-wake cycle } \\
\text { assessment }\end{array}$ & Melatonin (MT) & Results & Major limitations \\
\hline $\begin{array}{l}\text { Tordjman et al. } \\
\text { (146) } \\
\text { France }\end{array}$ & Case-control study & $\begin{array}{l}\text { Post-pubertal individuals } \\
\text { with autism }(N=43) \text { and } \\
\text { TD controls }(N=26)\end{array}$ & $\begin{array}{l}\text { DSM-IV-TR, ICD-10 } \\
\text { diagnostic criteria; ADI-R; } \\
\text { Wechsler intelligence scale; } \\
\text { Kaufman K-ABC }\end{array}$ & & $\begin{array}{l}\text { Daytime and } \\
\text { nighttime urinary } \\
\text { excretion of 6-SM } \\
\text { during a 24-h period. }\end{array}$ & $\begin{array}{l}\text { Low 6-SM excretion in autism; } \\
\text { nocturnal excretion of 6-SM was } \\
\text { negatively correlated with autism } \\
\text { severity in the overall level of verbal } \\
\text { language and repetitive use of } \\
\text { objects. }\end{array}$ & $\begin{array}{l}\text { No evaluation of } \\
\text { sleep parameters. }\end{array}$ \\
\hline $\begin{array}{l}\text { Wang et al. (147) } \\
\text { Beijing, Republic } \\
\text { of China }\end{array}$ & Case-control study & $\begin{array}{l}398 \text { patients with autism } \\
\text { ( } 2-17 \text { years); } 437 \text { healthy } \\
\text { controls. }\end{array}$ & $\begin{array}{l}\text { DSM-IV diagnostic criteria; } \\
\text { Autism Behavior Checklist } \\
\text { (ABC); CARS. }\end{array}$ & & $\begin{array}{l}\text { They sequenced all } \\
\text { ASMT exons and } \\
\text { their neighboring } \\
\text { region. }\end{array}$ & $\begin{array}{l}\text { The study did not detect significant } \\
\text { differences of genotypic distribution } \\
\text { and allele frequencies of the } \\
\text { common SNPs in ASMT between } \\
\text { patients with autism and healthy } \\
\text { controls; new rare coding mutations } \\
\text { of ASMT. }\end{array}$ & $\begin{array}{l}\text { Small sample size; } \\
\text { lack of clinical } \\
\text { information; } \\
\text { not sequence } \\
\text { other genes } \\
\text { in melatonin } \\
\text { pathway. }\end{array}$ \\
\hline $\begin{array}{l}\text { Jonsson et al. } \\
\text { (148) } \\
\text { Sweden }\end{array}$ & $\begin{array}{l}\text { Cross-sectional } \\
\text { study }\end{array}$ & $\begin{array}{l}1747 \text { subjects ( } 357 \\
\text { monozygotic (MZ) twin } \\
\text { pairs, } 500 \text { dizygotic (DZ) } \\
\text { twin pairs, and } 33 \text { subjects } \\
\text { without their co-twin). }\end{array}$ & $\begin{array}{l}\text { Telephonic interview: The } \\
\text { Autism-Tics, ADHD and } \\
\text { other Comorbidities is a } \\
\text { sensitive tool for screening } \\
\text { the general population for } \\
\text { child ASDs and associated } \\
\text { conditions. }\end{array}$ & & $\begin{array}{l}\text { Analysis of the SNPs } \\
\text { and the duplication of } \\
\text { exons } 2-8 \text { in ASMT. } \\
\text { A panel of } 47 \text { SNPs } \\
\text { to determine twin } \\
\text { zygosity. }\end{array}$ & $\begin{array}{l}\text { Significant association, in girls, } \\
\text { between an intronic SNP and } \\
\text { social interaction impairment and } \\
\text { restricted and repetitive behavior } \\
\text { where the C-allele carriers were } \\
\text { shown to have higher scores. They } \\
\text { also investigated a microduplication } \\
\text { of exons } 2-8 \text { in the ASMT gene, } \\
\text { which was found in } 27 \text { individuals } \\
(1.7 \%) \text {. All these individuals had } \\
\text { one extra copy of the region } \\
\text { investigated, except for one MZ } \\
\text { twin pair, who had two extra copies. } \\
\text { This duplication was analyzed with } \\
\text { respect to the total ASD scores, } \\
\text { although no significant associations } \\
\text { could be shown. }\end{array}$ & $\begin{array}{l}\text { Small sample size; } \\
\text { no evaluation of } \\
\text { sleep parameters. }\end{array}$ \\
\hline $\begin{array}{l}\text { Goldman et al. } \\
\text { (149) } \\
\text { Nashville, USA }\end{array}$ & $\begin{array}{l}\text { Cross-sectional } \\
\text { study }\end{array}$ & $\begin{array}{l}9 \text { children (3-10 years) } \\
\text { and took at least } 30 \text { min } \\
\text { or longer at baseline to fall } \\
\text { asleep on three or more } \\
\text { nights (by parent report } \\
\text { and actigraphy), free of } \\
\text { psychotropic medication. }\end{array}$ & $\begin{array}{l}\text { DSM-IV-TR diagnostic } \\
\text { criteria; ADOS. }\end{array}$ & $\begin{array}{l}\text { Comprehensive } \\
\text { sleep interview; } \\
\text { video-EEG-PSG; } \\
\text { actigraphy; CSHQ. }\end{array}$ & $\begin{array}{l}\text { Endogenous } \\
\text { plasma melatonin } \\
\text { dim light melatonin } \\
\text { onset (DLMO) } \\
\text { and supplemental } \\
\text { melatonin. }\end{array}$ & $\begin{array}{l}\text { In endogenous samples, maximal } \\
\text { melatonin concentration and } \\
\text { time to peak concentration were } \\
\text { comparable to the literature } \\
\text { results for TD children. DLMO } \\
\text { were captured in the majority of } \\
\text { children. Children with ASD and } \\
\text { insomnia responsive to low dose } \\
\text { melatonin treatment have relatively } \\
\text { normal profiles of endogenous and } \\
\text { supplemental melatonin. }\end{array}$ & $\begin{array}{l}\text { Small sample size, } \\
\text { lack of a control } \\
\text { group; variability in } \\
\text { the specific start } \\
\text { time of the serial } \\
\text { blood sampling. }\end{array}$ \\
\hline
\end{tabular}




\begin{tabular}{|c|c|c|c|c|c|c|c|}
\hline $\begin{array}{l}\text { Authors } \\
\text { (Ref.) } \\
\text { country }\end{array}$ & Study design & Sample size & ASD assessment & $\begin{array}{l}\text { Sleep-wake cycle } \\
\text { assessment }\end{array}$ & Melatonin (MT) & Results & Major limitations \\
\hline $\begin{array}{l}\text { Pagan et al. (150) } \\
\text { Paris Autism } \\
\text { Research } \\
\text { International Sib- } \\
\text { pair study }\end{array}$ & $\begin{array}{l}\text { Case-control } \\
\text { study; multicentric } \\
\text { study }\end{array}$ & $\begin{array}{l}278 \text { patients with ASD, } \\
\text { their } 506 \text { first-degree } \\
\text { relatives (129 unaffected } \\
\text { siblings, } 199 \text { mothers and } \\
178 \text { fathers); } 416 \text { sex- and } \\
\text { age-matched controls. }\end{array}$ & $\begin{array}{l}\text { Social Responsiveness } \\
\text { Scale (SRS), in first-degree } \\
\text { relatives and in controls; } \\
\text { RBS (Repetitive Behavior } \\
\text { Scale) for probands and } \\
\text { their relatives; ADI-R; } \\
\text { Diagnostic Interview for } \\
\text { Genetic Studies for adults } \\
\text { and Kiddie-Schedule for } \\
\text { Affective Disorders and } \\
\text { Schizophrenia for children; } \\
\text { Wechsler scales or Raven's } \\
\text { progressive matrices for } \\
\text { nonverbal individuals. }\end{array}$ & $\begin{array}{l}\text { Sleep self-report } \\
\text { and/or parent } \\
\text { questionnaire; } \\
\text { CSHQ; actigraphy; } \\
\text { Pittsburgh Sleep } \\
\text { Quality Index; a } \\
\text { self-assessment } \\
\text { questionnaire } \\
\text { to determine } \\
\text { morningness- } \\
\text { eveningness in } \\
\text { human circadian } \\
\text { rhythms; Epworth } \\
\text { sleepiness scale. }\end{array}$ & $\begin{array}{l}\text { Whole-blood } \\
\text { serotonin was } \\
\text { measured by high- } \\
\text { performance liquid } \\
\text { chromatography. } \\
\text { Plasma melatonin } \\
\text { was measured using } \\
\text { a radioimmunoassay. } \\
\text { NAS and 14-3-3 } \\
\text { were determined } \\
\text { in platelet pellets; } \\
\text { urine samples were } \\
\text { collected overnight } \\
\text { (2000-0800 hours) } \\
\text { from } 16 \text { adult patients } \\
\text { with HFA and } 10 \\
\text { adult controls; 6-SM } \\
\text { was measured by a } \\
\text { radio immunological } \\
\text { method. }\end{array}$ & $\begin{array}{l}\text { Patients showed higher serotonin } \\
\text { and NAS levels and lower } \\
\text { melatonin levels than healthy } \\
\text { controls. Impairments of melatonin } \\
\text { synthesis in ASD may be linked } \\
\text { with decreased } 14-3-3 \text { proteins. } \\
\text { The melatonin deficit was only } \\
\text { significantly associated with } \\
\text { insomnia. }\end{array}$ & $\begin{array}{l}\text { The assessment } \\
\text { of melatonin only } \\
\text { from plasma } \\
\text { sampled in the } \\
\text { morning; the } \\
\text { association } \\
\text { finding was not } \\
\text { fully replicated in } \\
\text { an independent } \\
\text { study. }\end{array}$ \\
\hline $\begin{array}{l}\text { Veatch et al. } \\
\text { (151) } \\
\text { Nashville, USA }\end{array}$ & Cross-sectional & $\begin{array}{l}15 \text { ASD children (3-9 } \\
\text { years) with sleep } \\
\text { disturbances of which } \\
11 \text { in treatment with } \\
\text { melatonin. }\end{array}$ & $\begin{array}{l}\text { DSM-IV-TR diagnostic } \\
\text { criteria; ADOS. }\end{array}$ & $\begin{array}{l}\text { Sleep interview } \\
\text { followed by } \\
\text { structured parent } \\
\text { education to } \\
\text { provide instructions } \\
\text { on daytime and } \\
\text { evening habits to } \\
\text { promote sleep. } \\
\text { Children were } \\
\text { confirmed to have } \\
\text { sleep onset delay } \\
\text { of at least } 30 \text { min } \\
\text { at baseline on C3 } \\
\text { nights per week, } \\
\text { and none had sleep } \\
\text { disturbance limited } \\
\text { to specific seasons. }\end{array}$ & $\begin{array}{l}\text { They evaluated } \\
\text { variation in two } \\
\text { melatonin pathway } \\
\text { genes, ASMT and } \\
\text { cytochrome P450 } \\
\text { 1A2 (CYP1A2). }\end{array}$ & $\begin{array}{l}\text { Higher frequencies than currently } \\
\text { reported for variants evidenced to } \\
\text { decrease ASMT expression and } \\
\text { related to decreased CYP1A2 } \\
\text { enzyme activity relationship } \\
\text { between genotypes in ASMT and } \\
\text { CYP1A2 }\end{array}$ & $\begin{array}{l}\text { Lack of a control } \\
\text { group; small size } \\
\text { sample; unable to } \\
\text { assess potential } \\
\text { differences } \\
\text { in ASMT and } \\
\text { CYP1A2 between } \\
\text { responders and } \\
\text { non-responder to } \\
\text { melatonin. }\end{array}$ \\
\hline
\end{tabular}




\begin{tabular}{|c|c|c|c|c|c|c|c|}
\hline $\begin{array}{l}\text { Authors } \\
\text { (Ref.) } \\
\text { country }\end{array}$ & Study design & Sample size & ASD assessment & $\begin{array}{l}\text { Sleep-wake cycle } \\
\text { assessment }\end{array}$ & Melatonin (MT) & Results & Major limitations \\
\hline $\begin{array}{l}\text { Abdulamir et al. } \\
\text { (152) } \\
\text { Baghdad, Iraq }\end{array}$ & Case-control study & $\begin{array}{l}60 \text { males with ASD } \\
\text { (3-13 years) divided } \\
\text { into } 3 \text { subgroups: mild, } \\
\text { moderate, and severe; } \\
26 \text { TD subjects age-/ } \\
\text { gender- matched. }\end{array}$ & DSM-5 diagnostic criteria. & $\begin{array}{l}76 \% \text { of autistic } \\
\text { subjects showed } \\
\text { sleep problems. } \\
\text { The severe autistic } \\
\text { patients showed } \\
\text { the highest number } \\
\text { of sleep problems } \\
\text { (18 patients) in } \\
\text { comparison with } \\
\text { moderate (15 } \\
\text { patients), and mild } \\
\text { autistic patients (13 } \\
\text { patients). }\end{array}$ & $\begin{array}{l}\text { Serum levels of } \\
\text { melatonin and } \\
\text { oxytocin. }\end{array}$ & $\begin{array}{l}\text { Levels of oxytocin and melatonin } \\
\text { in patients were significantly lower } \\
\text { than that of age-matched and } \\
\text { gender-matched controls and were } \\
\text { associated with the severity of the } \\
\text { disease that was indicated by the } \\
\text { significant decrease in the levels of } \\
\text { oxytocin and melatonin in moderate } \\
\text { patients. }\end{array}$ & $\begin{array}{l}\text { Small sample size; } \\
\text { only single area; } \\
\text { no systematic } \\
\text { assessment } \\
\text { of sleep-wake } \\
\text { rhythm. }\end{array}$ \\
\hline $\begin{array}{l}\text { Pagan et al. (153) } \\
\text { France }\end{array}$ & $\begin{array}{l}\text { Cross-sectional } \\
\text { study }\end{array}$ & $\begin{array}{l}\text { Melatonin: } 9 \text { patients and } \\
22 \text { controls; gut samples } \\
\text { for serotonin: } 11 \text { patients } \\
\text { and } 13 \text { controls; blood } \\
\text { platelets: } 239 \text { individuals } \\
\text { with ASD and their first- } \\
\text { degree relatives and } 278 \\
\text { controls. }\end{array}$ & $\begin{array}{l}\text { DSM-IV-TR diagnostic } \\
\text { criteria. }\end{array}$ & & $\begin{array}{l}\text { Melatonin in plasma } \\
\text { and tissues was } \\
\text { measured using a } \\
\text { radioimmunoassay; } \\
\text { serotonin was } \\
\text { measured by high- } \\
\text { performance liquid } \\
\text { chromatography; } \\
\text { NAS, AANAT, } \\
\text { and ASMT were } \\
\text { determined by } \\
\text { radio enzymology; } \\
\text { the amount of } \\
\text { 14-3-3 proteins was } \\
\text { determined using the } \\
\text { commercial 14-3-3 } \\
\text { Pro ELISA kit. }\end{array}$ & $\begin{array}{l}\text { Melatonin deficit in ASD, reduction } \\
\text { of AANAT and ASMT observed in } \\
\text { the pineal gland as well as in gut } \\
\text { and platelets of patients. Reduced } \\
\text { levels of 14-3-3 proteins that } \\
\text { regulate AANAT and ASMT activities } \\
\text { and increased levels of miR-451. }\end{array}$ & $\begin{array}{l}\text { Small samples } \\
\text { size; no evaluation } \\
\text { of sleep } \\
\text { parameters. }\end{array}$ \\
\hline
\end{tabular}




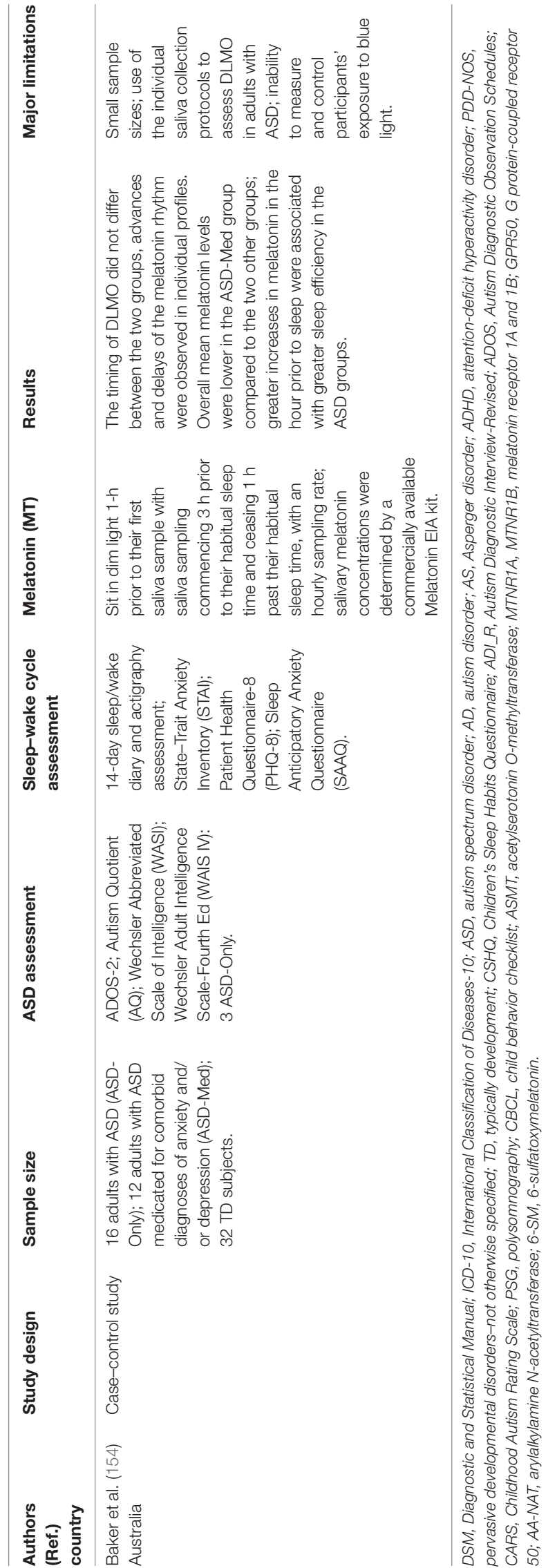

circadian sleep rhythmicity and ASD, but the nature of their link remains unclear. The literature on adult population is scant compared to studies on children. Although few studies have investigated this topic in adult subjects, similar results have been found compared to children. As shown in our results, studies have reported a high frequency of sleep problems and alterations of circadian sleep rhythmicity in ASD across all ages $(55,65,71,95,108,109,114,125)$. Difficulties in falling asleep, frequent nighttime awakenings, and short sleep duration were the sleep disturbances most frequently described in both children and adults with ASD $(72,78,79,124,130)$. Accordingly, these results were also confirmed by means of actigraphic and polysomnographic registration, displaying specific irregular sleep-wake cycles, low sleep efficiency, long sleep latency, insomnia, daytime sleepiness (68, 91, 97, 106, $119,120,132,133,134,136,137)$, delayed circadian phases, and evening preference as chronotype associated with ASD. According to our searches, polymorphisms in CLOCK genes that regulate sleep may be associated with $\operatorname{ASD}(25,26,59$, 60 ). Evidence is not strong although there are four separate studies implicating the alteration in CLOCK gene expression in the dysregulation of circadian sleep rhythmicity in ASD $(25,26,59,60)$. Melatonin dysregulation, which includes delay in melatonin peak, reduction in amplitude, and alteration in melatonin gene expression, may also contribute to circadian sleep desynchronization in ASD [for an overview, see Ref. (155)]. In some studies, blood, salivary, or urinary levels of melatonin or of its metabolites have been shown to be reduced in autistic subjects $(138-140,145,150)$ and to be correlated directly or indirectly with severe autistic behaviors such as verbal communication as well as repetitive behaviors and daytime sleepiness $(146,152)$. According to our results, abnormalities in melatonin-related genes (enzymes involved in melatonin synthesis, metabolism andor melatonin receptor function) may be related to low melatonin levels in ASD or may lead to an altered response to melatonin in a proportion of individuals with ASD $(141-143,148,153)$.

Several studies pointed out the potential correlation between sleep disturbances and the severity of autistic symptoms above all repetitive behaviors and deficits in verbal communication and/or in social reciprocity $(73,100,103,109,113,156,157)$. In summary the current data have shown several striking findings with regard to sleep/circadian sleep function and ASD, but the nature of the link remains unclear. We may hypothesize that polymorphisms in clock genes and alterations in melatonin pathways may contribute to the dysregulation of the circadian sleep rhythmicity and consequently to the dysregulation of sleep system in toto. According to the theories about the functions of sleep during development $(30,36-40)$, we may hypothesize that sleep disturbances may negatively influence brain maturation, contributing to autism symptoms. It has already been hypothesized that even a modest and initial impairment of circadian sleep rhythmicity may increase the individual's vulnerability to ASD [for an overview, see Ref. (11)]. Indeed, on the other hand, autistic symptoms may reinforce sleep disturbances, creating a self-reinforcing feedback loop (Figure 2). This framework should be useful in order to identify elements 


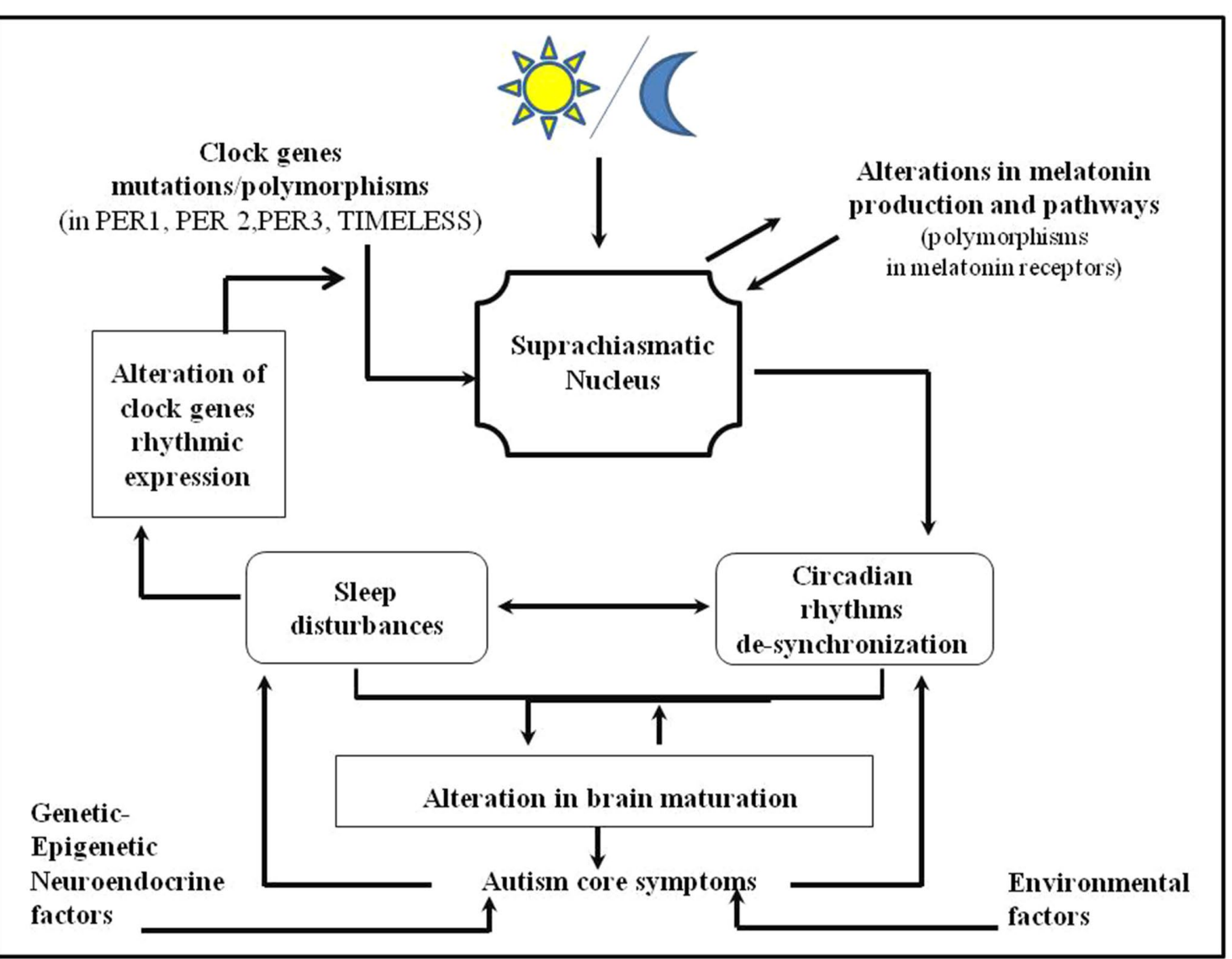

FIGURE 2 | Integrative model of the relationship between autism spectrum disorders, circadian and sleep dysrhythmicity. Polymorphism in clock genes and alterations in melatonin pathways may contribute to alterations in circadian sleep rhythms and consequently in the sleep regulation in toto. Altered sleep may negatively influence the brain maturation contributing to the autism core symptomatology. Vice versa, autism symptomatology may reinforce sleep disturbances creating a self-reinforcing loop between them.

to evaluate and target in the clinical practice. In particular, sleep disturbances and circadian sleep alterations may represent a novel therapeutic target in ASD. According to this model, by treating sleep and circadian sleep disorders in ASD, we should contribute to an improvement in ASD symptoms. There is strong evidence about the use of melatonin in ASD, indicating its beneficial effects on sleep and autistic symptoms. As suggested by some studies (158-165), melatonin may improve sleep difficulties in ASD subjects even when administered in association with concurrent psychotropic medications (160) and/or cognitive behavior therapy (164). Treatment with melatonin seems to improve sleep disturbances in the majority of children and adults with autistic symptoms (166), showing effectiveness on sleep duration, sleep latency, and nocturnal and early morning awakenings (158, 159, 161-165, 167, 168). Most importantly, by treating sleep and circadian sleep disorders with melatonin, an improvement in typical autistic behaviors has been shown in some studies $(158,163,168)$. Data in children with neurodevelopmental disorders failed to point to serious adverse events associated with the use of melatonin $(160,162$, $153,165,169)$ except for morning sleepiness (165), headache, and fatigue (167). These findings shed light on a rising hypothesis of an integrative model that may explain the interference of circadian rhythms and its variables during critical periods of brain development in ASD (Figure 2). Evaluating and targeting sleep disturbances and circadian sleep disorders in ASD should be useful to improve the trajectory of ASD. Indeed, the current data have shown a "research gap" about this topic. Future research should focus on the systematic study of circadian sleep dysrhythmicity in children and adults with ASD in relation to clock gene expression and to melatonin production.

\section{LIMITATIONS}

Our findings should be considered in the light of several limitations. Primarily, although this review aimed to summarize the most relevant studies on the relation between circadian sleep disorders and ASD, the inclusion/exclusion of specific studies may reflect our individual point of view or expertise and training. Moreover, some studies included may have been underpowered (some had only small sample sizes and small numbers of 
subjects enrolled) and/or some of them did not include control groups. Another limitation was the heterogeneity of the studies regarding the characteristics of the sample such as age, scholarity, study design, diagnostic criteria and measures of assessment, severity of sleep, and autistic symptoms that are potentially very important and should be considered routinely in future studies. Since the studies included in our research cover a wide temporal range (1984-2019), it is necessary to consider the nosography evolution of neurodevelopmental disorders over time, which could be a further study limitation. Psychiatric comorbidity and/or the use of psychopharmacological drugs may interfere with the duration and severity of both autistic symptoms and sleep disturbances. In addition, the potential roles of inert brain anomalies, the potential impact of brain injury during childbirth, and the potential influence of adverse environmental stressors in the early development of the child need to be addressed in further studies as being potential reasons for an apparent rise in the prevalence of ASD symptoms with later developmental stages.

\section{CONCLUSION}

Overall, results from this systematic review highlight the idea that sleep and circadian sleep disturbances are frequent in subjects

\section{REFERENCES}

1. American Psychiatric Association. Diagnostic and statistical manual of mental disorders 5th edition, DSM-5. Washington, DC (2013). doi: 10.1176/ appi.books.9780890425596

2. American Psychiatric Association. Diagnostic and statistical manual of mental disorders. IV edition-text revision, DSM-IV-TR. Washington, DC (2000).

3. Fernell E, Landgren M, Lindstrom K, Johnson M, Gillberg C. Children and young people with neurodevelopmental problems: support and efforts must be given even if not all diagnostic criteria are met. Lakartidningen (2013) 110(38):1674.

4. Charman T, Pickles A, Simonoff E, Chandler S, Loucas T, Baird G. IQ in children with autism spectrum disorders: data from the Special Needs and Autism Project (SNAP). Psychol Med (2011) 41(3):619-27. doi: 10.1017/ S0033291710000991

5. Klin A, Klaiman C, Jones W. Reducing age of autism diagnosis: developmental social neuroscience meets public health challenge. Rev Neurol (2015) 60 Suppl 1:S3-11.

6. Belardinelli C, Raza M, Taneli T. Comorbid behavioral problems and psychiatric disorders in autism spectrum disorders. J Child Dev Disord (2016) 2:11. doi: 10.4172/2472-1786.100019

7. Baio J, Wiggins L, Christensen DL, Maenner MJ, Daniels J, Warren Z, et al. Prevalence of autism spectrum disorder among children aged 8 years-autism and Developmental Disabilities Monitoring Network, 11 sites, United States, 2014. MMWR Surveill Summ (2018) 67(6):1-23. doi: 10.15585/mmwr.ss6706al

8. Brugha T, Spiers N, Bankart J, Cooper S, McManus S, Scott F, et al. Epidemiology of autism in adults across age groups and ability levels. $\mathrm{Br} \mathrm{J}$ Psychiatry (2016) 209(6):498-503. doi: 10.1192/bjp.bp.115.174649

9. Dell'Osso L, Abelli M, Pini S, Carpita B, Carlini M, Mengali F, et al. The influence of gender on social anxiety spectrum symptoms in a sample of university students. Riv Psichiatr (2015) 50(6):295-301. doi: 10.1708/2098.22688

10. Dell'Osso L, Carpita B, Cremone IM, Muti D, Diadema E, Barberi FM, et al. The mediating effect of trauma and stressor related symptoms and with autistic symptoms who have shown polymorphisms in clock gene expression and in genes involved in melatonin production. The impairment of circadian sleep regulation may increase the individual's vulnerability to develop symptoms of ASD by impairing the sleep regulation in toto, which instead plays a key role in normal brain development. Even though controversies and "research gaps" are present in literature at this point, we may hypothesize a bidirectional relation between circadian sleep dysfunction and ASD. In particular, circadian sleep dysrhythmicity may predispose to develop ASD symptoms and vice versa within a self-reinforcing loop. An early identification and assessment of circadian sleep dysrhythmicity could be useful for improving treatment strategies in both children and adults with ASD.

\section{AUTHOR CONTRIBUTIONS}

LP, CC, LD'O, DC, and IM designed the study and finalized the article. IM and DC managed the literature search. IM and DC elaborated the PubMed results and developed the first draft of the manuscript. LP and CC reviewed the manuscript. LP, CC, AV, $\mathrm{LN}$, and LD'O revised the final version. All authors contributed to and approved the final manuscript. ruminations on the relationship between autistic traits and mood spectrum Psychiatry Res (2018). doi: 10.1016/j.psychres.2018.10.040

11. Geoffray MM, Nicolas A, Speranza M, Georgieff N. Are circadian rhythms new pathways to understand Autism Spectrum Disorder? J Physiol Paris (2016) 110(4 Pt B):434-8. doi: 10.1016/j.jphysparis.2017.06.002

12. Gliga T, Jones EJ, Bedford R, Charman T, Johnson MH. From early markers to neuro-developmental mechanisms of autism. Dev Rev (2014) 34(3):189207. doi: 10.1016/j.dr.2014.05.003

13. Siu MT, Weksberg R. Epigenetics of autism spectrum disorder. Adv Exp Med Biol (2017) 978:63-90. doi: 10.1007/978-3-319-53889-1_4

14. Tordjman S, Anderson GM, Kermarrec S, Bonnot O, Geoffray MM, Brailly-Tabard S, et al. Altered circadian patterns of salivary cortisol in lowfunctioning children and adolescents with autism. Psychoneuroendocrinology (2014) 50:227-45. doi: 10.1016/j.psyneuen.2014.08.010

15. McClung CA. Mind your rhythms: an important role for circadian genes in neuroprotection. J Clin Invest (2013) 123(12):4994-6. doi: 10.1172/JCI73059

16. Reppert SM, Weaver DR. Coordination of circadian timing in mammals. Nature (2002) 418(6901):935-41. doi: 10.1038/nature00965

17. Bellivier F, Geoffroy PA, Etain B, Scott J. Sleep- and circadian rhythmassociated pathways as therapeutic targets in bipolar disorder. Expert Opin Ther Targets (2015) 19(6):747-63. doi: 10.1517/14728222.2015.1018822

18. Aas M, Kauppi K, Brandt CL, Tesli M, Kaufmann T, Steen NE, et al. Childhood trauma is associated with increased brain responses to emotionally negative as compared with positive faces in patients with psychotic disorders. Psychol Med (2017) 47(4):669-79. doi: 10.1017/S0033291716002762

19. Foster RG, Kreitzman L. The rhythms of life: what your body clock means to you! Exp Physiol (2014) 99(4):599-606. doi: 10.1113/expphysiol.2012.071118

20. Roenneberg T, Merrow M. Entrainment of the human circadian clock. Cold Spring Harb Symp Quant Biol (2007) 72:293-9. doi: 10.1101/sqb. 2007.72.043

21. Kalsbeek A, Merrow M, Roenneberg T, Foster RG. Neurobiology of circadian timing. Preface Prog Brain Res (2012) 199:11-2. doi: 10.1016/ B978-0-444-59427-3.00031-9

22. Zee PC, Vitiello MV. Circadian rhythm sleep disorder: irregular sleep wake rhythm type. Sleep Med Clin (2009) 4(2):213-8. doi: 10.1016/j.jsmc.2009.01. 009 
23. Richdale AL, Schreck KA. Sleep problems in autism spectrum disorders: prevalence, nature, and possible biopsychosocial aetiologies. Sleep Med Rev (2009) 13(6):403-11. doi: 10.1016/j.smrv.2009.02.003

24. Wimpory D, Nicholas B, Nash S. Social timing, clock genes and autism: a new hypothesis. J Intellect Disabil Res (2002) 46(Pt 4):352-8. doi: 10.1046/j.1365-2788.2002.00423.x

25. Nicholas B, Rudrasingham V, Nash S, Kirov G, Owen MJ, Wimpory DC. Association of Per1 and Npas2 with autistic disorder: support for the clock genes/social timing hypothesis. Mol Psychiatry (2007) 12(6):581-92. doi: 10.1038/sj.mp.4001953

26. Yang Z, Matsumoto A, Nakayama K, Jimbo EF, Kojima K, Nagata K, et al. Circadian-relevant genes are highly polymorphic in autism spectrum disorder patients. Brain Dev (2016) 38(1):91-9. doi: 10.1016/j.braindev.2015.04.006

27. Laposky A, Easton A, Dugovic C, Walisser J, Bradfield C, Turek F. Deletion of the mammalian circadian clock gene BMAL1/Mop3 alters baseline sleep architecture and the response to sleep deprivation. Sleep (2005) 28(4):395409. doi: 10.1093/sleep/28.4.395

28. Naylor E, Bergmann BM, Krauski K, Zee PC, Takahashi JS, Vitaterna MH, et al. The circadian clock mutation alters sleep homeostasis in the mouse. J Neurosci (2000) 20(21):8138-43. doi: 10.1523/JNEUROSCI.20-21-08138. 2000

29. Frank MG. Sleep and developmental plasticity not just for kids. Prog Brain Res (2011) 193:221-32. doi: 10.1016/B978-0-444-53839-0.00014-4

30. Feinberg I, Campbell IG. Longitudinal sleep EEG trajectories indicate complex patterns of adolescent brain maturation. Am J Physiol Regul Integr Comp Physiol (2013) 304(4):R296-303. doi: 10.1152/ajpregu.00422.2012

31. Kurth S, Olini N, Huber R, LeBourgeois M. Sleep and early cortical development. Curr Sleep Med Rep (2015) 1(1):64-73. doi: 10.1007/ s40675-014-0002-8

32. Marks GA, Shaffery JP, Oksenberg A, Speciale SG, Roffwarg HP. A functional role for REM sleep in brain maturation. Behav Brain Res (1995) 69(1-2):111. doi: 10.1016/0166-4328(95)00018-O

33. Mirmiran M, Van Someren E. Symposium: normal and abnormal REM sleep regulation: the importance of REM sleep for brain maturation. J Sleep Res (1993) 2(4):188-92. doi: 10.1111/j.1365-2869.1993.tb00088.x

34. Peirano PD, Algarin CR. Sleep in brain development. Biol Res (2007) 40(4):471-8. doi: 10.4067/S0716-97602007000500008

35. Li W, Ma L, Yang G, Gan WB. REM sleep selectively prunes and maintains new synapses in development and learning. Nature neuroscience (2017) 20(3):427-37. doi: 10.1038/nn.4479

36. Lindemann C, Ahlbeck J, Bitzenhofer SH, Hanganu-Opatz IL. Spindle activity orchestrates plasticity during development and sleep. Neural Plast (2016) 2016:5787423. doi: 10.1155/2016/5787423

37. Cirelli C, Tononi G. Sleep and synaptic homeostasis. Sleep (2015) 38(1):1612. doi: $10.5665 /$ sleep. 4348

38. Feinberg I, Davis NM, de Bie E, Grimm KJ, Campbell IG. The maturational trajectories of NREM and REM sleep durations differ across adolescence on both school-night and extended sleep. Am J Physiol Regul Integr Comp Physiol (2012) 302(5):R533-40. doi: 10.1152/ajpregu.00532.2011

39. Ringli M, Huber R. Developmental aspects of sleep slow waves: linking sleep, brain maturation and behavior. Prog Brain Res (2011) 193:63-82. doi: 10.1016/B978-0-444-53839-0.00005-3

40. Buchmann A, Ringli M, Kurth S, Schaerer M, Geiger A, Jenni OG, et al. EEG sleep slow-wave activity as a mirror of cortical maturation. Cereb Cortex (2011) 21(3):607-15. doi: 10.1093/cercor/bhq129

41. Bellesi M, Pfister-Genskow M, Maret S, Keles S, Tononi G, Cirelli C. Effects of sleep and wake on oligodendrocytes and their precursors. J Neurosci (2013) 33(36):14288-300. doi: 10.1523/JNEUROSCI.5102-12.2013

42. Cirelli C, Gutierrez CM, Tononi G. Extensive and divergent effects of sleep and wakefulness on brain gene expression. Neuron (2004) 41(1):35-43. doi: 10.1016/S0896-6273(03)00814-6

43. Hinard V, Mikhail C, Pradervand S, Curie T, Houtkooper RH, Auwerx J, et al. Key electrophysiological, molecular, and metabolic signatures of sleep and wakefulness revealed in primary cortical cultures. J Neurosci (2012) 32(36):12506-17. doi: 10.1523/JNEUROSCI.2306-12.2012

44. Gregory AM, Sadeh A. Sleep, emotional and behavioral difficulties in children and adolescents. Sleep Med Rev (2012) 16(2):129-36. doi: 10.1016/j. smrv.2011.03.007
45. Paus T, Keshavan M, Giedd JN. Why do many psychiatric disorders emerge during adolescence? Nat Rev Neurosci (2008) 9(12):947-57. doi: 10.1038/ nrn2513

46. Sadeh A, Tikotzky L, Kahn M. Sleep in infancy and childhood: implications for emotional and behavioral difficulties in adolescence and beyond. Curr Opin Psychiatry (2014) 27(6):453-9. doi: 10.1097/YCO.0000000000000109

47. Gregory AM, Caspi A, Eley TC, Moffitt TE, Oconnor TG, Poulton R. Prospective longitudinal associations between persistent sleep problems in childhood and anxiety and depression disorders in adulthood. J Abnorm Child Psychol (2005) 33(2):157-63. doi: 10.1007/s10802-005-1824-0

48. Sadeh A, Flint-Ofir E, Tirosh T, Tikotzky L. Infant sleep and parental sleep-related cognitions. J Fam Psychol (2007) 21(1):74-87. doi: 10.1037/ 0893-3200.21.1.74

49. Tesler N, Gerstenberg M, Huber R. Developmental changes in sleep and their relationships to psychiatric illnesses. Curr Opin Psychiatry (2013) 26(6):572-9. doi: 10.1097/YCO.0b013e328365a335

50. Simola P, Liukkonen K, Pitkaranta A, Pirinen T, Aronen ET. Psychosocial and somatic outcomes of sleep problems in children: a 4-year follow-up study. Child Care Health Dev (2014) 40(1):60-7. doi: 10.1111/j.1365-2214. 2012.01412.x

51. Touchette E, Petit D, Seguin JR, Boivin M, Tremblay RE, Montplaisir JY. Associations between sleep duration patterns and behavioral/cognitive functioning at school entry. Sleep (2007) 30(9):1213-9. doi: 10.1093/ sleep/30.9.1213

52. Volk C, Huber R. Sleep to grow smart? Arch Ital Biol (2015) 153(2-3):99109. doi: $10.12871 / 000398292015235$

53. Palagini L, Domschke K, Benedetti F, Foster RG, Wulff K, Riemann D. Developmental pathways towards mood disorders in adult life: is there a role for sleep disturbances? J Affect Disord (2019) 243:121-32. doi: 10.1016/j. jad.2018.09.011

54. Geiger A, Achermann P, Jenni OG. Sleep, intelligence and cognition in a developmental context: differentiation between traits and state-dependent aspects. Progress in Brain Research (2010) 167-79. doi: 10.1016/b978-0-44453702-7.00010-5

55. Díaz-Román A, Zhang J, Delorme R, Beggiato A, Cortese S. Sleep in youth with autism spectrum disorders: systematic review and meta-analysis of subjective and objective studies. Evid Based Mental Health (2018) 21(4):14654. doi: 10.1136/ebmental-2018-300037

56. American Psychiatric Association. Diagnostic and statistical manual of mental disorders. IV edition, DSM-IV. Washington, DC (1994).

57. Takase M, Taira M, Sasaki H. Sleep-wake rhythm of autistic children. Psychiatry Clin Neurosci (1998) 52(2):181-2. doi: 10.1111/j.1440-1819.1998.tb01017.x

58. Giannotti F, Cortesi F, Cerquiglini A, Miraglia D, Vagnoni C, Sebastiani T, et al. An investigation of sleep characteristics, EEG abnormalities and epilepsy in developmentally regressed and non-regressed children with autism. J Autism Dev Disord (2008) 38(10):1888-97. doi: 10.1007/s10803-008-0584-4

59. Mullegama SV, Alaimo JT, Chen L, Elsea SH. Phenotypic and molecular convergence of 2q23.1 deletion syndrome with other neurodevelopmental syndromes associated with autism spectrum disorder. Int J Mol Sci (2015) 16(4):7627-43. doi: 10.3390/ijms16047627

60. Goto M, Mizuno M, Matsumoto A, Yang Z, Jimbo EF, Tabata H, et al. Role of a circadian-relevant gene NR1D1 in brain development: possible involvement in the pathophysiology of autism spectrum disorders. Sci Rep (2017) 7:43945. doi: 10.1038/srep43945

61. van der Heijden KB, Stoffelsen RJ, Popma A, Swaab H. Sleep, chronotype, and sleep hygiene in children with attention-deficit/hyperactivity disorder, autism spectrum disorder, and controls. Eur Child Adolesc Psychiatry (2018) 27(1):99-111. doi: 10.1007/s00787-017-1025-8

62. Hoshino Y, Watanabe H, Yashima Y, Kaneko M, Kumashiro H. An investigation on sleep disturbance of autistic children. Folia Psychiatr Neurol Jpn (1984) 38(1):45-51. doi: 10.1111/j.1440-1819.1984.tb00353.x

63. Richdale AL, Prior MR. The sleep/wake rhythm in children with autism. Eur Child Adolesc Psychiatry (1995) 4(3):175-86. doi: 10.1007/BF01980456

64. Patzold LM, Richdale AL, Tonge BJ. An investigation into sleep characteristics of children with autism and Asperger's disorder. J Paediatr Child Health (1998) 34(6):528-33. doi: 10.1046/j.1440-1754.1998.00291.x

65. Taira M, Takase M, Sasaki H. Sleep disorder in children with autism. Psychiatry Clin Neurosci (1998) 52(2):182-3. doi: 10.1111/j.1440-1819.1998.tb01018.x 
66. Diomedi M, Curatolo P, Scalise A, Placidi F, Caretto F, Gigli GL. Sleep abnormalities in mentally retarded autistic subjects: Down's syndrome with mental retardation and normal subjects. Brain Dev (1999) 21(8):548-53. doi: 10.1016/S0387-7604(99)00077-7

67. Hering E, Epstein R, Elroy S, Iancu DR, Zelnik N. Sleep patterns in autistic children. J Autism Dev Disord (1999) 29(2):143-7. doi: 10.1023/A:1023092627223

68. Godbout R, Bergeron C, Limoges E, Stip E, Mottron L. A laboratory study of sleep in Asperger's syndrome. Neuroreport (2000) 11(1):127-30. doi: 10.1097/00001756-200001170-00025

69. Elia M, Ferri R, Musumeci SA, Del Gracco S, Bottitta M, Scuderi C, et al. Sleep in subjects with autistic disorder: a neurophysiological and psychological study. Brain Dev (2000) 22(2):88-92. doi: 10.1016/S0387-7604(99)00119-9

70. Honomichl RD, Goodlin-Jones BL, Burnham M, Gaylor E, Anders TF. Sleep patterns of children with pervasive developmental disorders. J Autism Dev Disord (2002) 32(6):553-61. doi: 10.1023/A:1021254914276

71. Wiggs L, Stores G. Sleep patterns and sleep disorders in children with autistic spectrum disorders: insights using parent report and actigraphy. Dev Med Child Neurol (2004) 46(6):372-80. doi: 10.1017/S0012162204000611

72. Gail Williams P, Sears LL, Allard A. Sleep problems in children with autism. J Sleep Res (2004) 13(3):265-8. doi: 10.1111/j.1365-2869.2004.00405.x

73. Schreck KA, Mulick JA, Smith AF. Sleep problems as possible predictors of intensified symptoms of autism. Res Dev Disabil (2004) 25(1):57-66. doi: 10.1016/j.ridd.2003.04.007

74. Polimeni MA, Richdale AL, Francis AJ. A survey of sleep problems in autism, Asperger's disorder and typically developing children. J Intellect Disabil Res (2005) 49(Pt 4):260-8. doi: 10.1111/j.1365-2788.2005.00642.x

75. Cotton S, Richdale A. Brief report: parental descriptions of sleep problems in children with autism, Down syndrome, and Prader-Willi syndrome. Res Dev Disabil (2006) 27(2):151-61. doi: 10.1016/j.ridd.2004.12.003

76. Allik H, Larsson JO, Smedje H. Sleep patterns of school-age children with Asperger syndrome or high-functioning autism. J Autism Dev Disord (2006) 36(5):585-95. doi: 10.1007/s10803-006-0099-9

77. Allik H, Larsson JO, Smedje H. Insomnia in school-age children with Asperger syndrome or high-functioning autism. BMC Psychiatry (2006) 6:18. doi: 10.1186/1471-244X-6-18

78. Krakowiak P, Goodlin-Jones B, Hertz-Picciotto I, Croen LA, Hansen RL. Sleep problems in children with autism spectrum disorders, developmental delays, and typical development: a population-based study. J Sleep Res (2008) 17(2):197-206. doi: 10.1111/j.1365-2869.2008.00650.x

79. Liu X, Hubbard JA, Fabes RA, Adam JB. Sleep disturbances and correlates of children with autism spectrum disorders. Child Psychiatry Hum Dev (2006) 37(2):179-91. doi: 10.1007/s10578-006-0028-3

80. Malow BA, Marzec ML, McGrew SG, Wang L, Henderson LM, Stone WL. Characterizing sleep in children with autism spectrum disorders: a multidimensional approach. Sleep (2006) 29(12):1563-71. doi: 10.1093/ sleep/29.12.1563

81. Miano S, Bruni O, Elia M, Trovato A, Smerieri A, Verrillo E, et al. Sleep in children with autistic spectrum disorder: a questionnaire and polysomnographic study. Sleep Med (2007) 9(1):64-70. doi: 10.1016/j.sleep.2007.01.014

82. Bruni O, Ferri R, Vittori E, Novelli L, Vignati M, Porfirio MC, et al. Sleep architecture and NREM alterations in children and adolescents with Asperger syndrome. Sleep (2007) 30(11):1577-85. doi: 10.1093/sleep/30.11.1577

83. DeVincent CJ, Gadow KD, Delosh D, Geller L. Sleep disturbance and its relation to DSM-IV psychiatric symptoms in preschool-age children with pervasive developmental disorder and community controls. J Child Neurol (2007) 22(2):161-9. doi: 10.1177/0883073807300310

84. Dominick KC, Davis NO, Lainhart J, Tager-Flusberg H, Folstein S. Atypical behaviors in children with autism and children with a history of language impairment. Res Dev Disabil (2007) 28(2):145-62. doi: 10.1016/j. ridd.2006.02.003

85. Allik H, Larsson JO, Smedje H. Sleep patterns in school-age children with Asperger syndrome or high-functioning autism: a follow-up study. J Autism Dev Disord (2008) 38(9):1625-33. doi: 10.1007/s10803-008-0543-0

86. Goodlin-Jones BL, Tang K, Liu J, Anders TF. Sleep patterns in preschoolage children with autism, developmental delay, and typical development. J Am Acad Child Adolesc Psychiatry (2008) 47(8):930-8. doi: 10.1097/CHI. ObO13e3181799f7c
87. Goodlin-Jones B, Schwichtenberg AJ, Iosif AM, Tang K, Liu J, Anders TF. Six-month persistence of sleep problems in young children with autism, developmental delay, and typical development. J Am Acad Child Adolesc Psychiatry (2009) 48(8):847-54. doi: 10.1097/CHI.0b013e3181a8135a

88. Goodlin-Jones B, Tang K, Liu J, Anders TF. Sleep problems, sleepiness and daytime behavior in preschool-age children. J Child Psychol Psychiatry (2009) 50(12):1532-40. doi: 10.1111/j.1469-7610.2009.02110.x

89. Paavonen EJ, Vehkalahti K, Vanhala R, von Wendt L, Nieminen-von Wendt T, Aronen ET. Sleep in children with Asperger syndrome. J Autism Dev Disord (2008) 38(1):41-51. doi: 10.1007/s10803-007-0360-x

90. Souders MC, Mason TB, Valladares O, Bucan M, Levy SE, Mandell DS, et al. Sleep behaviors and sleep quality in children with autism spectrum disorders. Sleep (2009) 32(12):1566-78. doi: 10.1093/sleep/32.12.1566

91. Goldman SE, Surdyka K, Cuevas R, Adkins K, Wang L, Malow BA. Defining the sleep phenotype in children with autism. Dev Neuropsychol (2009) 34(5):560-73. doi: 10.1080/87565640903133509

92. Buckley AW, Rodriguez AJ, Jennison K, Buckley J, Thurm A, Sato S, et al. Rapid eye movement sleep percentage in children with autism compared with children with developmental delay and typical development. Arch Pediatr Adolesc Med (2010) 164(11):1032-7. doi: 10.1001/archpediatrics.2010.202

93. Giannotti F, Cortesi F, Cerquiglini A, Vagnoni C, Valente D. Sleep in children with autism with and without autistic regression. J Sleep Res (2011) 20(2):338-47. doi: 10.1111/j.1365-2869.2010.00882.x

94. Anders TF, Iosif AM, Schwichtenberg AJ, Tang K, Goodlin-Jones BL. Sixmonth sleep-wake organization and stability in preschool-age children with autism, developmental delay, and typical development. Behav Sleep Med (2011) 9(2):92-106. doi: 10.1080/15402002.2011.557991

95. Rzepecka H, McKenzie K, McClure I, Murphy S. Sleep, anxiety and challenging behaviour in children with intellectual disability and/or autism spectrum disorder. Res Dev Disabil (2011) 32(6):2758-66. doi: 10.1016/j.ridd.2011.05.034

96. Schwichtenberg AJ, Iosif AM, Goodlin-Jones B, Tang K, Anders T. Daytime sleep patterns in preschool children with autism, developmental delay, and typical development. Am J Intellect Dev Disabil (2011) 116(2):142-52. doi: 10.1352/1944-7558-116.2.142

97. Anders T, Iosif AM, Schwichtenberg AJ, Tang K, Goodlin-Jones B. Sleep and daytime functioning: a short-term longitudinal study of three preschool-age comparison groups. Am J Intellect Dev Disabil (2012) 117(4):275-90. doi: 10.1352/1944-7558-117.4.275

98. Goldman SE, Richdale AL, Clemons T, Malow BA. Parental sleep concerns in autism spectrum disorders: variations from childhood to adolescence. J Autism Dev Disord (2012) 42(4):531-8. doi: 10.1007/s10803-011-1270-5

99. Sikora DM, Johnson K, Clemons T, Katz T. The relationship between sleep problems and daytime behavior in children of different ages with autism spectrum disorders. Pediatrics (2012) 130 Suppl 2:S83-90. doi: 10.1542/ peds.2012-0900F

100. Taylor MA, Schreck KA, Mulick JA. Sleep disruption as a correlate to cognitive and adaptive behavior problems in autism spectrum disorders. Res Dev Disabil (2012) 33(5):1408-17. doi: 10.1016/j.ridd.2012.03.013

101. Sivertsen B, Posserud MB, Gillberg C, Lundervold AJ, Hysing M. Sleep problems in children with autism spectrum problems: a longitudinal population-based study. Autism (2012) 16(2):139-50. doi: 10.1177/1362361311404255

102. Baker E, Richdale A, Short M, Gradisar M. An investigation of sleep patterns in adolescents with high-functioning autism spectrum disorder compared with typically developing adolescents. Dev Neurorehabil (2013) 16(3):15565. doi: 10.3109/17518423.2013.765518

103. Hollway JA, Aman MG, Butter E. Correlates and risk markers for sleep disturbance in participants of the Autism Treatment Network. J Autism Dev Disord (2013) 43(12):2830-43. doi: 10.1007/s10803-013-1830-y

104. Humphreys JS, Gringras P, Blair PS, Scott N, Henderson J, Fleming PJ, et al. Sleep patterns in children with autistic spectrum disorders: a prospective cohort study. Arch Dis Child (2014) 99(2):114-8. doi: 10.1136/ archdischild-2013-304083

105. Nadeau JM, Arnold EB, Keene AC, Collier AB, Lewin AB, Murphy TK. Frequency and clinical correlates of sleep-related problems among anxious youth with autism spectrum disorders. Child Psychiatry Hum Dev (2015) 46(4):558-66. doi: 10.1007/s10578-014-0496-9

106. Richdale AL, Baker E, Short M, Gradisar M. The role of insomnia, presleep arousal and psychopathology symptoms in daytime impairment in 
adolescents with high-functioning autism spectrum disorder. Sleep Med (2014) 15(9):1082-8. doi: 10.1016/j.sleep.2014.05.005

107. Hodge D, Carollo TM, Lewin M, Hoffman CD, Sweeney DP. Sleep patterns in children with and without autism spectrum disorders: developmental comparisons. Res Dev Disabil (2014) 35(7):1631-8. doi: 10.1016/j. ridd.2014.03.037

108. Tudor ME, Walsh CE, Mulder EC, Lerner MD. Pain as a predictor of sleep problems in youth with autism spectrum disorders. Autism (2015) 19(3):292-300. doi: 10.1177/1362361313518994

109. May T, Cornish K, Conduit R, Rajaratnam SM, Rinehart NJ. Sleep in highfunctioning children with autism: longitudinal developmental change and associations with behavior problems. Behav Sleep Med (2015) 13(1):2-18. doi: 10.1080/15402002.2013.829064

110. Mazurek MO, Petroski GF. Sleep problems in children with autism spectrum disorder: examining the contributions of sensory over-responsivity and anxiety. Sleep Med (2015) 16(2):270-9. doi: 10.1016/j.sleep.2014.11.006

111. Wang G, Liu Z, Xu G, Jiang F, Lu N, Baylor A, Owens J. Sleep disturbances and associated factors in Chinese children with autism spectrum disorder: a retrospective and cross-sectional study. Child Psychiatry Hum Dev (2016) 47(2):248-58. doi: 10.1007/s10578-015-0561-Z

112. Hirata I, Mohri I, Kato-Nishimura K, Tachibana M, Kuwada A, KagitaniShimono K, et al. Sleep problems are more frequent and associated with problematic behaviors in preschoolers with autism spectrum disorder. Res Dev Disabil (2016) 49-50:86-99. doi: 10.1016/j.ridd.2015.11.002

113. Hundley RJ, Shui A, Malow BA. Relationship between subtypes of restricted and repetitive behaviors and sleep disturbance in autism spectrum disorder. J Autism Dev Disord (2016) 46(11):3448-57. doi: 10.1007/s10803-016-2884-4

114. Irwanto N, Rehatta M, Hartini S, Takada S. Sleep problem of children with autistic spectrum disorder assessed by Children Sleep Habits Questionnaire-Abbreviated in Indonesia and Japan. Kobe J Med Sci (2016) 62(2):E22-6.

115. Fletcher FE, Foster-Owens MD, Conduit R, Rinehart NJ, Riby DM, Cornish KM. The developmental trajectory of parent-report and objective sleep profiles in autism spectrum disorder: associations with anxiety and bedtime routines. Autism (2017) 21(4):493-503. doi: 10.1177/1362361316653365

116. Mazurek MO, Sohl K. Sleep and behavioral problems in children with autism spectrum disorder. J Autism Dev Disord (2016) 46(6):1906-15. doi: 10.1007/ s10803-016-2723-7

117. Kheirouri S, Kalejahi P, Noorazar SG. Plasma levels of serotonin, gastrointestinal symptoms, and sleep problems in children with autism. Turk J Med Sci (2016) 46(6):1765-72. doi: 10.3906/sag-1507-68

118. Mutluer T, Karakoc Demirkaya S, Abali O. Assessment of sleep problems and related risk factors observed in Turkish children with Autism spectrum disorders. Autism Res (2016) 9(5):536-42. doi: 10.1002/aur.1542

119. Veatch OJ, Reynolds A, Katz T, Weiss SK, Loh A, Wang L, et al. Sleep in children with autism spectrum disorders: how are measures of parent report and actigraphy related and affected by sleep education? Behav Sleep Med (2016) 14(6):665-76. doi: 10.1080/15402002.2015.1065408

120. Aathira R, Gulati S, Tripathi M, Shukla G, Chakrabarty B, Sapra S, et al. Prevalence of sleep abnormalities in Indian children with autism spectrum disorder: a cross-sectional study. Pediatr Neurol (2017) 74:62-7. doi: 10.1016/j.pediatrneurol.2017.05.019

121. Kose S, Yilmaz H, Ocakoglu FT, Ozbaran NB. Sleep problems in children with autism spectrum disorder and intellectual disability without autism spectrum disorder. Sleep Med (2017) 40:69-77. doi: 10.1016/j.sleep.2017.09.021

122. Sannar EM, Palka T, Beresford C, Peura C, Kaplan D, Verdi M, Grados M. Sleep problems and their relationship to maladaptive behavior severity in psychiatrically hospitalized children with autism spectrum disorder (ASD). $J$ Autism Dev Disord (2018) 48(11):3720-6. doi: 10.1007/s10803-017-3362-3

123. Veatch OJ, Sutcliffe JS, Warren ZE, Keenan BT, Potter MH, Malow BA. Shorter sleep duration is associated with social impairment and comorbidities in ASD. Autism Res (2017) 10(7):1221-38. doi: 10.1002/aur.1765

124. Verhoeff ME, Blanken LME, Kocevska D, Mileva-Seitz VR, Jaddoe VWV, White $\mathrm{T}$, et al. The bidirectional association between sleep problems and autism spectrum disorder: a population-based cohort study. Mol Autism (2018) 9:8. doi: 10.1186/s13229-018-0194-8

125. Malow BA, Katz T, Reynolds AM, Shui A, Carno M, Connolly HV, et al. Sleep difficulties and medications in children with autism spectrum disorders: a registry study. Pediatrics (2016) 137 Suppl;2:98-104. doi: 10.1542/ peds.2015-2851H

126. Hare DJ, Jones S, Evershed K. A comparative study of circadian rhythm functioning and sleep in people with Asperger syndrome. Autism (2006a) 10(6):565-75. doi: 10.1177/1362361306068509

127. Hare DJ, Jones S, Evershed K. Objective investigation of the sleep-wake cycle in adults with intellectual disabilities and autistic spectrum disorders. J Intellect Disabil Res (2006b) 50(Pt 10):701-10. doi: 10.1111/j.1365-2788.2006.00830.x

128. Baker EK, Richdale AL. Examining the behavioural sleep-wake rhythm in adults with autism spectrum disorder and no comorbid intellectual disability. J Autism Dev Disord (2017) 47(4):1207-22. doi: 10.1007/s10803-017-3042-3

129. Goldman SE, Alder ML, Burgess HJ, Corbett BA, Hundley R, Wofford D, et al. Characterizing sleep in adolescents and adults with autism spectrum disorders. J Autism Dev Disord (2017) 47(6):1682-95. doi: 10.1007/s10803-017-3089-1

130. Ballester P, Martinez MJ, Javaloyes A, Inda MD, Fernandez N, Gazquez P, et al. Sleep problems in adults with autism spectrum disorder and intellectual disability. Autism Res (2019) 12(1):66-79. doi: 10.1002/aur.2000

131. Tani P, Lindberg N, Nieminen-von Wendt $T$, von Wendt $L$, Alanko L, Appelberg B, Porkka-Heiskanen T. Insomnia is a frequent finding in adults with Asperger syndrome. BMC Psychiatry (2003) 3:12. doi: $10.1186 / 1471-244 \mathrm{x}-3-12$

132. Tani P, Lindberg N, Nieminen-von Wendt T, von Wendt L, Virkkala J, Appelberg B, Porkka-Heiskanen T. Sleep in young adults with Asperger syndrome. Neuropsychobiology (2004) 50(2):147-52. doi: 10.1159/000079106

133. Tani $\mathrm{P}$, Lindberg N, Nieminen-von Wendt $\mathrm{T}$, von Wendt L, Alanko L, Appelberg B, Porkka-Heiskanen T. Actigraphic assessment of sleep in young adults with Asperger syndrome. Psychiatry Clin Neurosci (2005) 59(2):206-8. doi: 10.1111/j.1440-1819.2005.01359.x

134. Limoges E, Mottron L, Bolduc C, Berthiaume C, Godbout R. Atypical sleep architecture and the autism phenotype. Brain (2005) 128(Pt 5):1049-61. doi: 10.1093/brain/awh425

135. Oyane NM, Bjorvatn B. Sleep disturbances in adolescents and young adults with autism and Asperger syndrome. Autism (2005) 9(1):83-94. doi: $10.1177 / 1362361305049031$

136. Limoges E, Bolduc C, Berthiaume C, Mottron L, Godbout R. Relationship between poor sleep and daytime cognitive performance in young adults with autism. Res Dev Disabil (2013) 34(4):1322-35. doi: 10.1016/j.ridd.2013. 01.013

137. Baker EK, Richdale AL. Sleep patterns in adults with a diagnosis of highfunctioning autism spectrum disorder. Sleep (2015) 38(11):1765-74. doi: 10.5665/sleep. 5160

138. Nir I, Meir D, Zilber N, Knobler H, Hadjez J, Lerner Y. Brief report: circadian melatonin, thyroid-stimulating hormone, prolactin, and cortisol levels in serum of young adults with autism. J Autism Dev Disord (1995) 25(6):64154. doi: 10.1007/BF02178193

139. Kulman G, Lissoni P, Rovelli F, Roselli MG, Brivio F, Sequeri P. Evidence of pineal endocrine hypofunction in autistic children. Neuro Endocrinol Lett (2000) 21(1):31-4.

140. Tordjman S, Anderson GM, Pichard N, Charbuy H, Touitou Y. Nocturnal excretion of 6-sulphatoxymelatonin in children and adolescents with autistic disorder. Biol Psychiatry (2005) 57(2):134-8. doi: 10.1016/j.biopsych.2004. 11.003

141. Melke J, Goubran Botros H, Chaste P, Betancur C, Nygren G, Anckarsater H, et al. Abnormal melatonin synthesis in autism spectrum disorders. Mol Psychiatry (2008) 13(1):90-8. doi: 10.1038/sj.mp.4002016

142. Chaste P, Clement N, Mercati O, Guillaume JL, Delorme R, Botros HG, et al. Identification of pathway-biased and deleterious melatonin receptor mutants in autism spectrum disorders and in the general population. PLoS One (2010) 5(7):e11495. doi: 10.1371/journal.pone.0011495

143. Jonsson L, Ljunggren E, Bremer A, Pedersen C, Landen M, Thuresson K, et al. Mutation screening of melatonin-related genes in patients with autism spectrum disorders. BMC Med Genomics (2010) 3:10. doi: 10. 1186/1755-8794-3-10

144. Mulder EJ, Anderson GM, Kemperman RF, Oosterloo-Duinkerken A, Minderaa RB, Kema IP. Urinary excretion of 5-hydroxyindoleacetic acid, serotonin and 6-sulphatoxymelatonin in normoserotonemic and hyperserotonemic autistic individuals. Neuropsychobiology (2010) 61(1):2732. doi: $10.1159 / 000258640$ 
145. Leu RM, Beyderman L, Botzolakis EJ, Surdyka K, Wang L, Malow BA. Relation of melatonin to sleep architecture in children with autism. J Autism Dev Disord (2011) 41(4):427-33. doi: 10.1007/s10803-010-1072-1

146. Tordjman S, Anderson GM, Bellissant E, Botbol M, Charbuy H, Camus F, et al. Day and nighttime excretion of 6-sulphatoxymelatonin in adolescents and young adults with autistic disorder. Psychoneuroendocrinology (2012) 37(12):1990-7. doi: 10.1016/j.psyneuen.2012.04.013

147. Wang L, Li J, Ruan Y, Lu T, Liu C, Jia M, et al. Sequencing ASMT identifies rare mutations in Chinese Han patients with autism. PLoS One (2013) 8(1):e53727. doi: 10.1371/journal.pone.0053727

148. Jonsson L, Anckarsater H, Zettergren A, Westberg L, Walum H, Lundstrom $\mathrm{S}$, et al. Association between ASMT and autistic-like traits in children from a Swedish nationwide cohort. Psychiatr Genet (2014) 24(1):21-7. doi: 10.1097/ YPG.0000000000000010

149. Goldman SE, Adkins KW, Calcutt MW, Carter MD, Goodpaster RL, Wang L, et al. Melatonin in children with autism spectrum disorders: endogenous and pharmacokinetic profiles in relation to sleep. J Autism Dev Disord (2014) 44(10):2525-35. doi: 10.1007/s10803-014-2123-9

150. Pagan C, Delorme R, Callebert J, Goubran-Botros H, Amsellem F, Drouot X, et al. The serotonin- $N$-acetylserotonin-melatonin pathway as a biomarker for autism spectrum disorders. Transl Psychiatry (2014) 4:e479. doi: 10.1038/ tp.2014.120

151. Veatch OJ, Pendergast JS, Allen MJ, Leu RM, Johnson CH, Elsea SH, et al. Genetic variation in melatonin pathway enzymes in children with autism spectrum disorder and comorbid sleep onset delay. J Autism Dev Disord (2015) 45(1):100-10. doi: 10.1007/s10803-014-2197-4

152. Abdulamir HA, Abdul-Rasheed OF, Abdulghani EA. Low oxytocin and melatonin levels and their possible role in the diagnosis and prognosis in Iraqi autistic children. Saudi Med J (2016) 37(1):29-36. doi: 10.15537/ smj.2016.1.13183

153. Pagan C, Goubran-Botros H, Delorme R, Benabou M, Lemiere N, Murray K, et al. Disruption of melatonin synthesis is associated with impaired 14-3-3 and miR-451 levels in patients with autism spectrum disorders. Sci Rep (2017) 7(1):2096. doi: 10.1038/s41598-017-02152-x

154. Baker EK, Richdale AL, Hazi A, Prendergast LA. Assessing the dim light melatonin onset in adults with autism spectrum disorder and no comorbid intellectual disability. J Autism Dev Disord (2017) 47(7):2120-37. doi: 10.1007/s10803-017-3122-4

155. Rossignol DA, Frye RE. Melatonin in autism spectrum disorders: a systematic review and meta-analysis. Dev Med Child Neurol (2011) 53(9): 783-92. doi: 10.1111/j.1469-8749.2011.03980.x

156. Tordjman S, Najjar I, Bellissant E, Anderson GM, Barburoth M, Cohen D, et al. Advances in the research of melatonin in autism spectrum disorders: literature review and new perspectives. Int J Mol Sci (2013) 14(10):20508-42. doi: 10.3390/ijms141020508

157. Tordjman S, Davlantis KS, Georgieff N, Geoffray MM, Speranza M, Anderson GM, et al. Autism as a disorder of biological and behavioral rhythms: toward new therapeutic perspectives. Front Pediatr (2015) 3:1. doi: 10.3389/fped.2015.00001

158. Garstang J, Wallis M. Randomized controlled trial of melatonin for children with autistic spectrum disorders and sleep problems. Child Care Health Dev (2006) 32(5):585-9. doi: 10.1111/j.1365-2214.2006.00616.x

159. Wasdell MB, Jan JE, Bomben MM, Freeman RD, Rietveld WJ, Tai J, et al. A randomized, placebo-controlled trial of controlled release melatonin treatment of delayed sleep phase syndrome and impaired sleep maintenance in children with neurodevelopmental disabilities. J Pineal Res (2008) 44(1):57-64. doi: 10.1111/j.1600-079X.2007.00528.x

160. Andersen IM, Kaczmarska J, McGrew SG, Malow BA. Melatonin for insomnia in children with autism spectrum disorders. J Child Neurol (2008) 23(5):482-5. doi: 10.1177/0883073807309783

161. Wirojanan J, Jacquemont S, Diaz R, Bacalman S, Anders TF, Hagerman RJ, et al. The efficacy of melatonin for sleep problems in children with autism, fragile X syndrome, or autism and fragile X syndrome. J Clin Sleep Med (2009) 5(2):145-50.

162. Wright B, Sims D, Smart S, Alwazeer A, Alderson-Day B, Allgar V, et al. Melatonin versus placebo in children with autism spectrum conditions and severe sleep problems not amenable to behaviour management strategies: a randomised controlled crossover trial. J Autism Dev Disord (2011) 41(2):175-84. doi: 10.1007/s10803-010-1036-5

163. Malow B, Adkins KW, McGrew SG, Wang L, Goldman SE, Fawkes D, et al. Melatonin for sleep in children with autism: a controlled trial examining dose, tolerability, and outcomes. J Autism Dev Disord (2012) 42(8):1729-37. doi: 10.1007/s10803-011-1418-3

164. Cortesi F, Giannotti F, Sebastiani T, Panunzi S, Valente D. Controlledrelease melatonin, singly and combined with cognitive behavioural therapy, for persistent insomnia in children with autism spectrum disorders: a randomized placebo-controlled trial. J Sleep Res (2012) 21(6):700-9. doi: 10.1111/j.1365-2869.2012.01021.x

165. Ayyash HF, Preece P, Morton R, Cortese S. Melatonin for sleep disturbance in children with neurodevelopmental disorders: prospective observational naturalistic study. Expert Rev Neurother (2015) 15(6):711-7. doi: 10. 1586/14737175.2015.1041511

166. Galli-Carminati G, Deriaz N, Bertschy G. Melatonin in treatment of chronic sleep disorders in adults with autism: a retrospective study. Swiss Med Wkly (2009) 139(19-20):293-6. doi: smw-12342

167. Gringras P, Nir T, Breddy J, Frydman-Marom A, Findling RL. Efficacy and safety of pediatric prolonged-release melatonin for insomnia in children with autism spectrum disorder. J Am Acad Child Adolesc Psychiatry (2017) 56(11):948-57.e944. doi: 10.1016/j.jaac.2017.09.414

168. Paavonen EJ, Nieminen-von Wendt T, Vanhala R, Aronen ET, von Wendt L. Effectiveness of melatonin in the treatment of sleep disturbances in children with Asperger disorder. J Child Adolesc Psychopharmacol (2003) 13(1):8395. doi: 10.1089/104454603321666225

169. Giannotti F, Cortesi F, Cerquiglini A, Bernabei P. An open-label study of controlled-release melatonin in treatment of sleep disorders in children with autism. J Autism Dev Disord (2006) 36(6):741-52. doi: 10.1007/ s10803-006-0116-Z

Conflict of Interest Statement: The authors declare that the research was conducted in the absence of any commercial or financial relationships that could be construed as a potential conflict of interest.

Copyright (C) 2019 Carmassi, Palagini, Caruso, Masci, Nobili, Vita and Dell'Osso. This is an open-access article distributed under the terms of the Creative Commons Attribution License (CC BY). The use, distribution or reproduction in other forums is permitted, provided the original author(s) and the copyright owner(s) are credited and that the original publication in this journal is cited, in accordance with accepted academic practice. No use, distribution or reproduction is permitted which does not comply with these terms. 